Universidad de Lima

Escuela de Posgrado

Maestría en Tributación y Política Fiscal

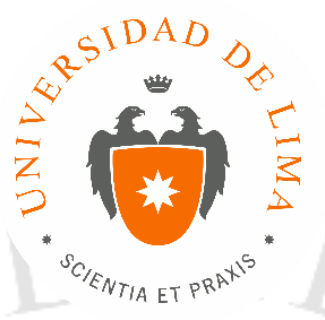

\title{
NATURALEZA DE LAS ÓRDENES DE PAGO. PROBLEMAS EN TORNO AL SUPUESTO CONTENIDO EN EL NUMERAL 3 DEL ARTÍCULO $78^{\circ}$ DEL CÓDIGO TRIBUTARIO
}

Trabajo de investigación para optar el Grado Académico de Maestro en

Tributación y Política Fiscal

Luis Alberto Perea Cacho

Código 20122443

Asesor

Cesar Gamba Valega

Lima - Perú

Julio de 2017 
NATURALEZA DE LAS ÓRDENES DE PAGO. PROBLEMAS EN TORNO AL SUPUESTO CONTENIDO EN EL NUMERAL 3 DEL ARTÍCULO $78^{\circ}$ DEL CÓDIGO TRIBUTARIO 


\section{TABLA DE CONTENIDO}

INTRODUCCIÓN 1

CAPÍTULO I: NATURALEZA DE LAS ÓRDENES DE PAGO ..................... 4

1.1 Relación jurídico tributaria y obligación tributaria .............................. 4

1.2 La obligación tributaria en la legislación nacional ............................. 6

1.3 Hipótesis de incidencia y hecho imponible ...................................... 8

1.4 La Determinación ............................................................................ 14

1.5 La Orden de Pago y su naturaleza ................................................. 23

\section{CAPÍTULO II: EJECUTORIEDAD DE LA ORDEN PAGO, SOLVE ET}

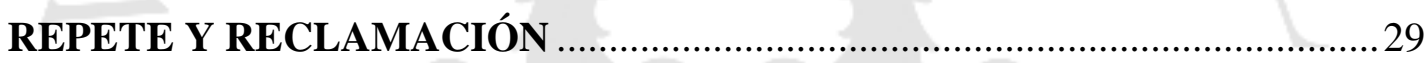

2.1 Ejecutoriedad de la orden de pago .................................................29

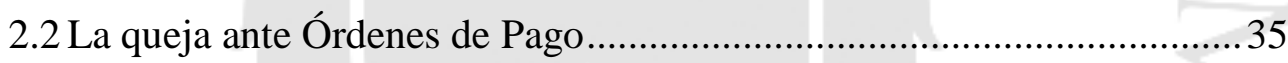

2.3 Reclamación contra la Orden de Pago - Solve Et Repete ......................41

\section{CAPÍTULO III: NUMERAL 3 DEL ARTÍCULO 78 DEL CÓDIGO}

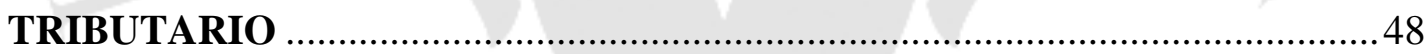

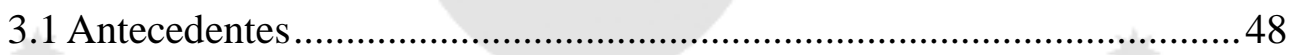

3.2 Error material de redacción o de cálculo ............................................50

3.3 La declaración jurada....................................................................54

3.4 Fundamentación en las Órdenes de Pago .............................................61

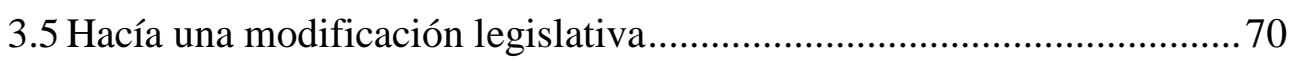

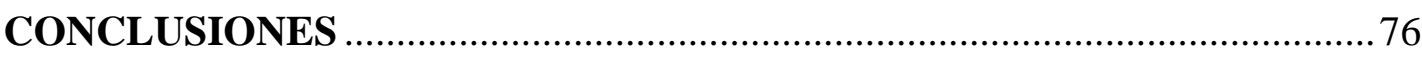

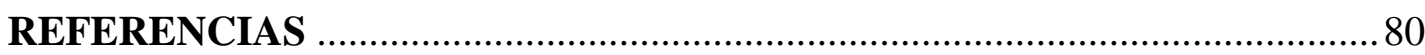




\section{INTRODUCCIÓN}

Ante la notificación de una Orden de Pago, dos pueden ser las reacciones del contribuyente, una primera, la de estar ante un recordatorio de pago de una deuda puesta en conocimiento de la Administración Tributaria por sí mismo a través de una declaración jurada, esto es, la Administración le recuerda que se encuentra pendiente de pago la deuda derivada de la obligación tributaria que declaró. Una segunda reacción será la de sorpresa ante una deuda respecto de la cual no tiene conocimiento, ya sea por su existencia o por el monto de la misma, esto es, el contribuyente considera no haber declarado lo que se le pretende cobrar.

Este segundo supuesto es el que nos lleva a realizar la presente investigación, la situación de incertidumbre que puede generar en ciertas circunstancias la notificación de una Orden de Pago, que aparejada con la casi inmediata cobranza coactiva de la deuda contenida en la misma, y más aún con los criterios establecidos por el Tribunal Fiscal al respecto, derivan en uno de los temas más complicados con los que puede enfrentarse un contribuyente.

El ser una situación que afecta por lo general a pequeños y medianos contribuyentes, nos parece que ha conllevado a que el tratamiento dado por la doctrina nacional sea mínimo, a pesar de ser un tema que genera gran controversia no solo en la propia Administración, sino también en el máximo órgano resolutor en materia tributaria como lo es el Tribunal Fiscal.

Consideramos pertinente que el análisis del problema planteado tenga como punto de partida una visión general de lo que se debe entender por obligación tributaria y la naturaleza de la Orden de Pago, para luego entrar a analizar el punto central del cual surgen los problemas, como lo es la emisión de Órdenes de Pago en virtud a lo dispuesto por el numeral $3 \mathrm{del}$ artículo $78^{\circ}$ del Código Tributario y todas las implicancias que puede acarrear.

Asimismo, se analizará en el presente trabajo el tema de le ejecución coactiva de las deudas contenidas en las Ordenes de Pago, de donde deriva en la práctica el 
problema principal con el que tiene que lidiar los contribuyentes afectados con la notificación de una valor de dicha naturaleza.

En un primer capítulo plantearemos el marco teórico que servirá de punto de partida a nuestro trabajo. Así, se empezará analizando el concepto de obligación tributaria y la determinación de la misma, poniendo incidencia en los conflictos que insiste en la doctrina al respecto, planteando nuestra posición, así como lo señalado por la legislación y la jurisprudencia nacional. Se tratará también el tema de la hipótesis de incidencia y el hecho imponible, los problemas en torno a la diferenciación de dichos conceptos tanto en la doctrina como en la legislación extranjera, y la posición tomada por la legislación nacional.

Trataremos igualmente el concepto de Orden de Pago, la emisión de dicho valores y los problemas que se pueden presentar al respecto, para finalmente plantear nuestra posición respecto a lo que entendemos por naturaleza de la Orden de Pago, lo cual servirá de base para analizar y desarrollar los problemas planteados.

Posteriormente se verá en un segundo capítulo el tema de la ejecutoriedad de las Órdenes de Pago, partiendo de la cobranza de las deudas tributarias y la facultad con que cuenta la Administración Tributaria para hacer efectiva de manera directa los actos de cobro de las mismas, para pasar luego a ver el tema de la exigibilidad de las deudas tributarias y lo establecido por el Código Tributario y la Ley del Procedimiento de Ejecución Coactiva al respecto, así como el Procedimiento de Cobranza Coactiva y los medios de defensa con los cuales puede contar un contribuyente que se vea afectado en sus derechos, poniendo énfasis en los pronunciamientos del Tribunal Fiscal emitidos en los últimos años, que han hecho que se vea mermada la capacidad de defensa de los contribuyentes en el caso de cobranzas coactivas de deudas contenidas en Ordenes de Pago, lo cual hace más preocupante aún el tema bajo análisis.

Aunado al tema antes citado, se analizarán los problemas que surgen en torno a las reclamaciones contra Órdenes de Pago, principalmente el tema del solve et repete, y su vinculación con el derecho de defensa.

En un tercer y último capítulo trataremos el tema de las Órdenes de Pago emitidas sobre la base de lo establecido por el numeral 3 del artículo $78^{\text {a }}$ del Código Tributario, dando énfasis de manera especial a lo que se debe entender por "errores materiales de redacción o de cálculo", repasando asimismo el tema de las declaraciones 
juradas y la plasmación de la autodeterminación de la obligación tributaria, tema el cual es de vital importancia para comprender los problemas que se pueden presentar en relación a la emisión de dicho tipo de Órdenes de Pago.

Igualmente trataremos el tema de la fundamentación como requisito de emisión de las Órdenes de Pago emitidas por "errores materiales de redacción o de cálculo", tema de lo más controversial y que veremos en relación a la nulidad o anulabilidad de dichos valores, y el tratamiento dispensado por el Tribunal Fiscal al respecto.

Concluiremos planteando nuestra posición respecto a una modificación legislativa, teniendo en cuenta los problemas derivados de la emisión del tipo de Órdenes de Pago analizadas, así como de la cobranza de las mismas, lo cual conlleva en muchos casos a la desnaturalización de dicho tipo de valor. Se planteará de manera previa el tema relacionado con las facultades con las cuales cuenta la Administración Tributaria, y si en virtud a estas puede la Administración actuar en concordancia con nuestro planteamiento. 


\section{CAPÍTULO I: NATURALEZA DE LAS ÓRDENES DE PAGO}

El objetivo del presente trabajo gira en torno a establecer la necesidad de una modificación legislativa en torno a la emisión de Órdenes de Pago en virtud a errores de cálculo o de redacción, con ese fin consideramos necesario abordar en este primer capítulo el tema de la naturaleza de las Órdenes de Pago.

De manera previa al análisis de lo que entendemos por naturaleza de la orden de pago, es de suma importancia tratar el tema de la obligación tributaria y su correspondiente determinación, temas los cuales han sido muy discutidos en la doctrina, sin encontrarse una posición unánime al respecto. Partiremos planteando las diversas posiciones que existen en la doctrina respecto de dichos conceptos y de algunos derivados de ellos, para luego plantear nuestra posición.

Consideramos de fundamental importancia exponer lo que entendemos por determinación de la obligación tributaria, en tanto dicho concepto se encuentra directamente relacionado con la esencia del tema de las órdenes de pago, es más, como expondremos más adelante, dicha relación forma parte fundamental de la posición que exponemos en el presente trabajo.

\subsection{Relación jurídico tributaria y obligación tributaria}

En primer lugar, veremos el tema de la obligación tributaria, su relación con el concepto de la relación jurídico tributaria, así como las posiciones doctrinarias y normativas al respecto.

Siguiendo a Giuliani Fonrouge (2004) al hacer el análisis de lo que se debe entender por obligación tributario, tenemos que:

El ejercicio del poder tributario tiene como propósito esencial exigir de los particulares

el pago de sumas de dinero o de cantidades de cosas si los tributos fueran en especie, lo que ha inducido a una parte de la doctrina a considerar a esa obligación como el centro del derecho tributario, relegando a segundo plano otras exigencias que reconocen el 
mismo origen. Hay situaciones, en efecto, en que el legislador impone al contribuyente y aun a terceras personas, el cumplimiento de múltiples actos o abstenciones tendientes a asegurar y facilitar la determinación y recaudación de tributos, motivando discrepancias en la apreciación de sus vínculos con la obligación de pagar. (p. 337)

No corresponde al presente trabajo realizar un análisis ontológico relativo a la naturaleza de la obligación tributaria, no obstante lo cual, es preciso señalar la existencia de ciertas discrepancias en torno a lo que se debe entender por dicho concepto. Así, siguiendo al citado Giuliani Fonrouge (p. 337), tenemos que cierto sector de la doctrina considera que la relación de orden jurídico establecida entre el estado y los particulares constituye la obligación tributaria, la cual puede tener contenido único o variado, en tanto que otro sector considera como tal a la obligación de satisfacer las prestaciones establecidas por ley, las cuales conjuntamente con las demás exigencias que tienen su origen en la ley, integran el concepto más amplio de relación jurídico tributaria, la cual calificaría como el género, de la cual la primera es la especie.

A partir de dicha discusión, surge la figura de la relación jurídica tributaria, establecida por Giannini (como se cita en Giuliani, 2004, p. 339), para el cual de las normas reguladoras de las obligaciones tributarias, se originan una serie de derechos y deberes recíprocos entre el Estado y los contribuyentes, todos los cuales forman parte de lo que se denomina como la relación jurídica tributaria, de la cual derivan poderes, derechos e incluso obligaciones de la Administración Tributaria, así como obligaciones y derechos de las personas que se sujetan a su potestad, entiéndase no solo contribuyentes, sino incluso terceros, de ahí el carácter esencialmente complejo de dicha relación.

Sainz de Bujanda (1993) hace la distinción entre relación jurídica tributaria en sentido amplio, la cual comprende los vínculos jurídicos producidos por la aplicación de la norma tributaria entre el ente público y los contribuyentes, de la relación tributaria en sentido estricto u obligación tributaria, la cual comprende únicamente el crédito del ente público y la consiguiente deuda tributaria a cargo de la persona obligada al pago. (p. 193 y 194)

La doctrina mayoritaria coincide en señalar que al hablar de relación jurídico tributaria, se está haciendo referencia a la relación tributaria principal, la misma que tiene por objeto el pago del tributo, sin negar la existencia de otras obligaciones accesorias, como es el caso del pago de intereses, pero dejándose de lado otro tipo de 
obligaciones, como las de los administrados frente a la administración (no acreedor tributario), las que surgen en los procesos tributarios, entre otras.

Entendemos nosotros a la relación jurídica tributaria, como aquella relación jurídica establecida por el Estado con total prescindencia de la voluntad del sujeto obligado, en tanto lo hace en virtud al ejercicio de su poder de imperio, la cual tiene como fuente a la ley, y que puede ser de carácter sustancial o principal, esto es, el pago del tributo, o de carácter formal o accesorio, cuando está referida al cumplimiento de otros deberes, como pueden ser la presentación de declaraciones juradas, inscripción, colaboración, etc.

La misma dirección sigue el Modelo del Código Tributario del CIAT, al conceptualizar en su artículo $19^{\circ}$ la relación jurídica tributaria como el conjunto de obligaciones y deberes materiales y formales, derechos y potestades que se originan por la aplicación de los tributos entre el Estado y los obligados tributarios (2015). Al respecto, en el comentario respectivo a dicha norma se indica que la aplicación de las normas jurídico tributarias da lugar a una pluralidad de vínculos y relaciones entre la Administración tributaria y los obligados y es a esta pluralidad de vínculos y relaciones a lo que se denomina relación jurídico tributaria. Por otra parte, el artículo $20^{\circ}$ del citado Modelo de Código Tributario, señala que de la relación jurídico tributaria pueden derivarse obligaciones tributarias materiales y formales tanto para el estado como para los obligados tributarios, siendo obligaciones tributarias materiales las de carácter principal, las de realizar pagos a cuenta o anticipados y de retener o percibir, así como todas las demás que tengan por objeto una prestación de dar de contenido económico, precisándose que por obligaciones formales se quiere aludir a aquellas que resultan complementarias a las obligaciones materiales, que se aplican a las personas, sean o no deudores tributarios y coadyuvan a su cumplimiento.

Es importante tratar a continuación, lo que la legislación tributaria nacional entiende por obligación tributaria, sin dejar de lado los conceptos antes vertidos, a efectos de plantear posteriormente nuestra posición.

\subsection{La obligación tributaria en la legislación nacional}

Según establece el artículo $1^{\circ}$ del Texto Único Ordenado del Código Tributario (Decreto Supremo N 133-2013-EF, 2013), la obligación tributaria, que es de derecho 
público, es el vínculo entre el acreedor y el deudor tributario, establecido por ley, que tiene por objeto el cumplimiento de la prestación tributaria, siendo exigible coactivamente.

La redacción del artículo $1^{\circ}$ de nuestro Código Tributario, está referida de manera específica a la obligación sustancial, lo cual no niega la existencia de obligaciones de carácter formal o accesorio planteadas a lo largo del referido cuerpo legal, tales como la establecida en el artículo $11^{\circ}$ en relación a la obligación de fijar y cambiar de domicilio fiscal, o las establecidas en los numerales 1 y 3 del artículo $87^{\circ}$, relacionadas con la obligación de inscribirse en los registros de la Administración Tributaria, y la de emitir y/u otorgar los comprobantes de pago o los documentos complementarios a éstos.

A manera de ejemplo de lo antes señalado, podemos citar jurisprudencia del Tribunal Fiscal que hace referencia a dicha distinción entre obligaciones sustanciales y obligaciones formales. Así, en la Resolución $N^{\circ}$ 6309-3-2007, se estableció que el cumplimiento de la obligación tributaria sustancial no exime del cumplimiento de la obligación tributaria formal, toda vez que los deudores tributarios se encuentran obligados a cumplir con sus obligaciones tributarias sustanciales y sus obligaciones tributarias formales teniendo en cuenta la forma, lugares $u$ otras condiciones que establezca la administración tributaria; en tanto que en la Resolución $\mathrm{N}^{\circ}$ 2406-2-2008, se señaló que, mientras las obligaciones sustanciales nacen con la realización de la hipótesis de incidencia prescrita en la norma, las obligaciones formales responden a otras circunstancias, como pueden ser la presentación de declaraciones juradas que contengan o no la determinación de la obligación tributaria, entre otros.

Al respecto, en lo concerniente a la obligación tributaria sustancial, nos parece pertinente citar a Jorge Bravo (2010), cuando señala que la misma:

(... ) es una relación jurídica que importa un deber jurídico de prestación de dar una suma de dinero con carácter definitivo de un sujeto deudor a favor de otro acreedor (quien en contraprestación detenta un derecho subjetivo o crédito tributario), cuya causa fuente es la incidencia de una norma jurídica en sentido estricto ante la ocurrencia, en el plano fáctico, de un supuesto de hecho previsto en la hipótesis de incidencia de dicha norma. (p. 332 y 333 )

Se puede concluir que la legislación nacional, el artículo $1^{\circ}$ del Código Tributario específicamente, cuando hace referencia a la obligación tributaria, se ciñe a lo que 
entendemos como obligación tributaria sustancial, por la cual el sujeto activo, ya sea el Estado u otra entidad pública, tiene la pretensión, y el sujeto pasivo o los sujetos pasivos, la obligación de dar una suma de dinero en cuanto se verifique el hecho previsto en la ley a tales efectos.

Así, a partir de lo dispuesto por la legislación nacional, podemos llegar a establecer un concepto de obligación tributaria, a la cual podemos definir como el vínculo jurídico por el cual el deudor tributario, se encuentra obligado a entregar al acreedor tributario sumas de dinero, en la mayoría de los casos, o entregar bienes e incluso servicios en algunos casos, pero teniendo presente que siempre estaremos ante una obligación de dar, formando parte dicha obligación de lo que se entiende por relación jurídico tributaria, siendo la obligación material por excelencia.

El Código Tributario peruano señala como una de las características de la obligación tributaria su pertenencia al derecho público, esto es, es una relación jurídica que se da entre el Estado y particulares, en la cual los particulares se encuentran en relación de subordinación frente al Estado, el cual actúa en ejercicio de su poder de imperio, contando así con una serie de privilegios y prerrogativas. Estamos así frente a un mandato el cual no puede ser modificado por la autonomía de las partes, como podría darse en el ámbito del derecho privado.

Habiendo expuesto nuestra posición en cuanto a lo que entendemos por obligación tributaria, pasaremos a analizar el tema de la hipótesis de incidencia y el hecho imponible, aspectos que nos llevan a ver el tema del nacimiento de la obligación tributaria.

\subsection{Hipótesis de incidencia y hecho imponible}

Ahora bien, la obligación tributaria tal como la entendemos, y como todo hecho jurídico, nace de la concretización en la realidad de un hecho descrito en la ley (de ahí su naturaleza de obligación ex lege) de manera hipotética, previa y genérica, esto es, el supuesto de hecho de la norma tributaria, respecto del cual nos parece oportuno hacer algunos precisiones conceptuales, en tanto existen criterios divergentes tanto en la doctrina como en la legislación comparada, habiendo optado la legislación nacional por una posición particular. 
Al respecto, tenemos que la Ley General Tributaria de España en su artículo 20.1, define al supuesto de hecho de la norma tributaria, al que denomina hecho imponible, como el presupuesto fijado por la ley para configurar cada tributo y cuya realización origina el nacimiento de la obligación tributaria principal.

Al respecto, Sainz de Bujanda (1993) manifiesta, al hacer referencia al hecho imponible en la legislación española según lo señalado en el párrafo anterior, que el hecho imponible cumple dos funciones principales: 1) Es el elemento generador de la obligación tributaria, y 2) Permite clasificar objetivamente a los tributos que integran el sistema. (p. 203)

De otro lado Jarach (1999), al conceptualizar el hecho imponible, señala que:

La ley no puede generar la obligación sin la existencia en la vida real del hecho imponible concreto que pueda subsumirse en la definición legal del hecho imponible abstracto. Por otro parte, el hecho imponible no crea por sí solo la obligación, sino que lo hace a través de la ley. (p. 381)

Partiendo de lo señalado por la legislación y doctrina española antes reseñada, se tiene que el supuesto de la norma tributaria es denominado por lo general, tanto por la doctrina como por las mismas legislaciones ${ }^{1}$, como hecho imponible, no obstante lo cual en el Perú, siguiendo la distinción terminológica popularizada por Geraldo Ataliba (1987), se conoce como hipótesis de incidencia, reservándose el concepto de hecho imponible para el hecho efectivamente acaecido en la realidad (p. 48 y ss). No obstante lo antes indicado, debe señalarse que no existe en la legislación peruana una definición general de lo que se debe entender como hipótesis de incidencia, término el cual no obstante si es recogido por la doctrina y la jurisprudencia, tanto del Tribunal Fiscal como del Tribunal Constitucional

En lo que respecta al Tribunal Fiscal, tenemos lo señalado, entre otras, por la Resolución N²406-3-2008, según la cual las obligaciones sustanciales nacen con la realización de la hipótesis de incidencia prevista en la norma; así como las Resoluciones $N^{\circ}$ 6839-1-2005 y 385-2-2006, en las cuales se señala que el Decreto de Alcaldía no es el instrumento legal idóneo para establecer los elemento de la hipótesis de incidencia.

\footnotetext{
${ }^{1}$ Tales como el Código Tributario chileno, el cual habla igualmente del hecho imponible como presupuesto contenido en la norma.
} 
De otro lado, el Tribunal Constitucional ha señalado en la Sentencia $N^{\circ}$ 19932008-PA/TC que el hecho imponible es un hecho de la vida, del mundo de los hechos, un acontecimiento empírico que recibe de la ley (hipótesis de incidencia) la calificación que lo vuelve apto para determinar el nacimiento de una obligación tributaria, es pues un hecho jurígeno. En tal sentido, no es posible pretender la nulidad de los hechos generadores de la hipótesis de incidencia tributaria, pues los hechos o situaciones sobre las que incide la norma tributaria no son actos jurídicos propios y puros sino más bien situaciones "jurígenas" debidamente constadas en el marco del procedimiento tributario, como es el hecho generador de riqueza o de utilidades sobre los que recae un impuesto como el Impuesto a la Renta.

Consideramos así pertinente, siguiendo a la jurisprudencia y doctrina nacional, denominar al supuesto de hecho de la norma tributaria como hipótesis de incidencia, en tanto que al hecho ocurrido o situación producida, concretización en la realidad del supuesto de hecho establecido en la norma, como hecho imponible.

Así, tenemos que la obligación tributaria nace al verificarse en la realidad la materialización de la hipótesis de incidencia diseñada por el legislador, recibiendo dicha situación fáctica el nombre de hecho imponible.

Al respecto, es importante tener en cuenta lo señalado por Barros Carvalho (2008), para quien:

(...) Ya en el universo jurídico, no existe necesidad lógica o factualmente fundada de que la hipótesis implique la consecuencia, siendo la propia norma quien establece el vínculo condicional, por medio del "deber ser" (...) en la ley de la causalidad jurídica es el sistema jurídico positivo el que determina, de entre las posibilidades, de entre las posibles hipótesis y consecuencias, las relaciones que se van a establecer. Es el acto de voluntad de la autoridad que legisla, expresado por un "deber ser" neutro, es decir, que no aparece modalizado en las formas "prohibido, "permitido" y "obligatorio", el responsable de la conexión deóntica entre proposición-antecedente y proposición-tesis. (p. 70).

De lo expuesto, se tiene que es por virtud de la ley, que a un hecho que sucede en la realidad se le asigna una consecuencia, la cual es el nacimiento de la obligación tributaria según la hemos conceptualizado. El hecho acaecido en la realidad, por su propia naturaleza no acarrea ninguna consecuencia sino que la consecuencia es otorgada por el legislador. 
La ordenanza tributaria alemana de 1919, la misma que constituye la base sobre la cual se cimentó en su gran mayoría el ordenamiento tributario europeo, establece al respecto en su numeral 38 que "Los créditos derivados de la obligación tributaria nacen cuando se realiza el supuesto de hecho al que la ley vincule el deber de prestación". (p. 74)

En lo que respecta a la legislación nacional, el nacimiento de la obligación tributaria se encuentra regulada en el artículo 2 del Código Tributario, el cual señala que la misma nace cuando se realiza el hecho previsto en la ley, como generador de dicha obligación, esto es, y siguiendo la línea ante señalada, la obligación tributaria nace cuando se verifica en la realidad, la realización del hecho imponible.

Ahora bien, es importante tener en cuenta que la hipótesis de incidencia tributaria comprende una serie de aspectos, los cuales deben estar contenidos necesariamente en la norma preestablecida para tales efectos, en cumplimiento del principio de legalidad. Así, tenemos que de acuerdo a lo dispuesto por el inciso a) de la Norma IV del Título Preliminar del Código Tributario, solo por ley o decreto legislativo, en caso de delegación, se puede crear, modificar y suprimir tributos; señalar el hecho generador de la obligación tributaria, la base para su cálculo y la alícuota; el acreedor tributario; el deudor tributario y el agente de tención o percepción, sin perjuicio de lo establecido en el artículo $10^{\circ 2}$.

El concepto de hipótesis de incidencia lleva implícito el de sus cuatro aspectos, esto es, el aspecto subjetivo, que responde a la pregunta quien, el aspecto objetivo o material, que responde a la pregunta que, el aspecto temporal, que responde a la pregunta cuándo, y el aspecto espacial que responde a la pregunta dónde.

Siendo que la hipótesis de incidencia constituye la descripción del hecho que pretende ser gravado, consideramos que la base imponible y la alícuota no deben ser consideradas como aspectos de la misma, en tanto que si bien son conceptos a tener en cuenta al efectuar la determinación de la obligación tributaria, no inciden en la descripción de tal hecho. En efecto, a fin de verificar si un hecho acaecido en la realidad se corresponde con el supuesto establecido en la norma tributaria, y por lo tanto, se encuentra gravado con un determinado tributo, corresponde verificarse si dicho hecho se encuentra previsto en la norma, su conexión con alguien, su localización en el país y

${ }^{2}$ Artículo $10^{\circ}$ del Código Tributario que trata sobre los agentes de retención o percepción. 
su consumación en un momento fáctico determinado, siendo el carácter mensurable del mismo, así como la alícuota a aplicarse, elementos no necesarios para determinar si estamos frente a un hecho gravado.

Corresponde en consecuencia, desarrollar los aspectos de la hipótesis de incidencia a que se ha hecho referencia.

a) Aspecto material.- Es la descripción objetiva de un hecho concreto realizado por el destinatario de la norma tributaria, o una situación en la cual se halla o respecto del cual se produce, tales como transferir bienes, obtener ganancias o beneficios, solicitar una autorización, gozar de un servicio público, entre otros. Tal como señala Villegas (2014) "El aspecto material del hecho imponible es el elemento descriptivo al cual, para completar el supuesto hipotético, se le adicionan los restantes elementos (personal, espacial y temporal)" (p. 274). Efectivamente, es en torno al aspecto material de la hipótesis de incidencia donde se configuran los demás aspectos, encontrándose ligado dicho aspecto siempre a un verbo y su complemento respectivo, tales como "vender bienes", "brindar servicios", "utilizar bienes", "ser propietario de inmuebles", etc.

El hecho descrito en la hipótesis de incidencia tiene tanto un sustrato económico como jurídico, siendo ambos importantes a efectos de comprender el mismo. Al respecto, Bravo Cucci (2010) señala que:

(...) en este aspecto encontramos la descripción hipotética del substrato económico (...), así como la mención expresa de circunstancias jurídicas que deben rodearlo y que son necesarias para la configuración del hecho imponible, tales como los efecto jurídicos derivados de una norma o de un negocio jurídico (el hecho de ser propietarios, el de realizar una transferencia de propiedad, entrega en uso, prestación de servicios, etc.), o inclusive de los propios negocios jurídicos. (p. 172)

Como señala el referido autor, para los efectos del tributo, no solo es importante el hecho económico sino las diversas consideraciones jurídicas que se señalen, tales como el de ser propietario, que se haya producido una transferencia, entre otros.

b) Aspecto espacial.- Es el aspecto que nos indica el lugar en el cual el sujeto realiza el hecho, o en el cual se tiene por realizado el hecho. A tales efectos, es importante tener en cuenta los criterios de vinculación económica, los cuales pueden ser 
política (nacionalidad o ciudadanía), social (domicilio o residencia) y económica (principio de la fuente).

Cabe señalar que no siempre aparecerá de forma expresa en la norma el lugar en el cual debe ocurrir el hecho para considerarlo como afecto al tributo, casos en los cuales se deberá estar a las condiciones implícitas señaladas por la norma para verificar donde debe ocurrir el hecho para ser incidido por la norma.

c) Aspecto temporal.- Indica el momento exacto en el cual se produce, o en el cual el legislador considera se debe entender por producido, el hecho descrito en el aspecto material. El legislador debe considerar que el hecho imponible se realiza en un momento específico, pudiendo recurrir para ello en algunos casos a las ficciones tributarias, esto a que el momento que se considere se realiza el hecho imponible, es fundamental para una serie de aspectos relativos a la aplicación de la norma tributaria, tales como la retroactividad, prescripción, intereses, etc.

Teniendo en cuenta el aspecto temporal de la hipótesis de incidencia, los tributos pueden considerarse como de realización inmediata como el Impuesto General a las Ventas, o de realización periódica como el Impuesto a la Renta.

d) Aspecto personal.- Se encuentra referido a aquel que realiza el hecho o se encuentra en la situación descrita en el aspecto material de la hipótesis de incidencia. Así la norma tributaria establecerá los aspectos a tenerse en cuenta a efectos de verificar en quienes recaerá la condición de sujeto activo y sujeto pasivo del tributo.

Villegas (2014) lo denomina destinatario legal tributario, calificando como tal aquel personaje respecto del cual el hecho imponible ocurre o se configura, esto es, “(...) el personaje que ejecuta el acto o se halla en la situación fáctica que la ley seleccionó como presupuesto hipotético y condicionante del mandato de pago de un tributo". (p. 355)

Si bien tal como hemos señalado, consideramos que la base imponible no forma parte de los aspectos de la hipótesis de incidencia, existen autores que han expresado una opinión en contrario, podemos citar así a Dino Jarach (1999), para quien:

La base imponible representa uno de los elementos constitutivos del hecho imponible y responde a la necesidad de cuantificar dicho presupuesto de hecho a fin de aplicar sobre esa cantidad el porcentaje o la escala progresiva cuya utilización dará como resultado el importe del hecho imponible y responde a la necesidad de cuantificar dicho 
presupuesto de hecho a fin de aplicar sobre esa cantidad el porcentaje o la escala progresiva cuya utilización dará como resultado el importe del impuesto. (p. 384)

Podemos definir a la base imponible como la perspectiva mensurable del aspecto material de la hipótesis de incidencia. Tal como se puede apreciar, existe una relación directa entre la base imponible y el aspecto material de la hipótesis de incidencia, tanto es así que se ha llegado a denominar, de manera incorrecta como señala Bravo Cucci (2010, p. 176), como el aspecto cuantitativo de la hipótesis de incidencia.

La base imponible asimismo, se encuentra estrechamente vinculada con el concepto de capacidad económica, esto es, con la potencialidad económica vinculada a la titularidad y disponibilidad de la riqueza; con la aptitud de un sujeto de derecho para hacer frente a la exigencia de una obligación tributaria concreta por parte de una Administración Pública. En consecuencia, puede considerarse a la base imponible como la cuantificación individual de la capacidad económica, Calvo Ortega (2000) señala en ese sentido que:

El hecho imponible concreta una capacidad económica general y abstracta y la base imponible la individualiza y la cuantifica para los contribuyentes en particular, más concretamente, la base imponible es la magnitud determinada de capacidad económica que se somete a gravamen. Estamos así en presencia de tres conceptos unidos por la necesidad de producir una obligación jurídica: la capacidad económica es un principio constitucional abstracto; el hecho imponible tiene una naturaleza jurídica y traduce individualmente el citado principio; y la base imponible cuantifica la capacidad económica que necesariamente tiene que manifestar, que expresar, el propio hacho imponible. El hecho imponible no se mide, porque es un hecho jurídico. Lo que se mide es la capacidad económica. (p. 228 y 229)

La base imponible como podemos apreciar, si bien no forma parte de los aspectos de la hipótesis de incidencia, es parte importante a efectos de determinar el quantum del tributo.

\subsection{La Determinación}

Una vez definidos estos primeros aspectos teóricos, nos podemos preguntar ¿Qué debemos entender por determinación de la obligación tributaria? 
Según lo señalado por el Código Tributario en los artículos $59^{\circ}$ y $60^{\circ}$, la determinación de la obligación tributaria puede iniciarse por acto o declaración del deudor tributario, quien verificará la realización del hecho generador de la obligación tributaria, señala la base imponible y la cuantía del tributo; o por la Administración Tributaria, quien además de verificar la realización de los aspectos antes mencionados, deberá identificar igualmente al deudor tributario.

En tal sentido, determinar la obligación tributaria implica comprobar la subsunción de un hecho acaecido en la realidad respecto a todo y cada uno de los elementos de la hipótesis de incidencia, fijando asimismo el aspecto mensurable del aspecto material de la hipótesis de incidencia, esto es, la base imponible, a la cual se aplicará la alícuota a efectos de fijar la cuantía del tributo. La referida subsunción debe ser total, no pudiendo existir una subsunción parcial, ya que la identidad entre la hipótesis de incidencia y el hecho imponible debe ser total, debiendo encontrarse presentes todos los aspectos que conforman la primera (material, temporal, espacial y personal), en la ocurrencia o verificación del segundo.

Dicha improcedencia de determinar una obligación tributaria en virtud de una subsunción parcial, por más que únicamente se encuentre ausente uno de los elementos conformantes de la hipótesis de incidencia, puede observarse de lo dispuesto en la Norma VIII del Título Preliminar del Código Tributario ${ }^{3}$, el cual establece claras limitaciones a la interpretación de las disposiciones tributarias, prohibiendo en especial la analogía en materia tributaria.

Villegas (2014) señala al respecto que la determinación tributaria "Es el acto o conjunto de actos dirigidos a precisar en cada caso si existe una deuda tributaria (an debeatur), quién es el obligado a pagar el tributo al fisco (sujeto pasivo) y cuál es el importe de la deuda (quantum tributario)”. (p. 395)

Asimismo, Giuliani Fonrouge (2004) señala que:

La ley establece, en forma objetiva y general, las circunstancias o presupuestos de hecho de cuya producción deriva la sujeción del tributo. Pero ese mandato indeterminado tiene su secuencia en una operación posterior, mediante la cual la norma

\footnotetext{
${ }^{3}$ Según el cual, al aplicar las normas tributarias podrá usarse todos los métodos de interpretación admitidos por el Derecho. En vía de interpretación no podrá crearse tributos, establecerse sanciones, concederse exoneraciones, ni extenderse las disposiciones tributarias a personas o supuestos distintos de los señalados en la ley
} 
de la ley se particulariza, se adapta a la situación de cada persona que pueda hallarse incluida en los presupuestos fácticos previstos; dicho de otra manera, la situación objetiva contemplada por la ley se concreta y exterioriza en cada caso particular. En materia tributaria, esta operación se llama determinación de la obligación. (p. 427)

En la doctrina nacional, tenemos lo señalado por Talledo Mazú (1999), quien define a la determinación como:

(...) el acto jurídico por el que se define la situación jurídica de un sujeto a consecuencia de la aplicación del tributo o del goce de un beneficio, de tal suerte que: a) si es efectuada por el sujeto pasivo es un acto jurídico de reconocimiento de su situación jurídico-tributaria realizado ante la Administración Tributaria por mandato legal, y b) si es realizada por la Administración Tributaria tiene la naturaleza de acto jurídico administrativo. (p. 98)

Asimismo, María Julia Sáenz Rabanal (1996) presenta una definición de lo que se debe entender por determinación tributaria:

(...) se refiere al acto o actos jurídicos a través de los cuales la Administración Tributaria, el sujeto pasivo, o ambos, pueden identificar en un sujeto concreto la existencia de un hecho gravado o deuda tributaria ("andebeatur"), señalando adicionalmente su cuantía (“quantum debeatur”). (p. 105)

Es oportuno señalar asimismo, que se aprecia en la doctrina que los términos determinación y liquidación son utilizados a menudo de manera indistinta, no obstante lo cual debe precisarse que se trata de términos jurídicos diferenciados, tanto es así que en nuestra legislación el término liquidación tiene un sentido restringido, en tanto se encuentra vinculado al aspecto final del proceso de determinación de la obligación, el cual tiene que ver específicamente con la cuantificación de la obligación, siendo así la liquidación parte de la determinación. Compartimos así lo expresado por Giuliani Fonrouge (2004, p. 427), para quien el término liquidación tiene un sentido más restringido, encontrándose vinculado al aspecto final de la determinación.

Respecto a la señalada confusión de términos, tenemos que el Modelo de Código Tributario para América Latina precisa en la exposición de motivos de los artículos $132^{\circ}$ a $138^{\circ}$ que se adopta la expresión “determinación” por ser corriente en diversos países, pero no desconoce que algunas veces se ha reemplazado por otras. Así, es frecuente el uso del vocablo liquidación y también el de acertamiento, buscando con esta última una equivalencia de la expresión italiana accertamento. 
Tal como hemos señalado, consideramos que el término liquidación implica la parte final de la determinación de la obligación, vinculada más con la cuantificación de la misma.

Cabe preguntarse ahora respecto a la naturaleza de la determinación, existiendo al respecto discrepancia en la doctrina, entre quienes sostiene la naturaleza constitutiva de la determinación tributaria, esto es, que con la determinación surge la obligación tributaria, y entre aquellos que sostienen la naturaleza declarativa de la misma, para quienes el acto de determinación constituye únicamente un acto que declara la existencia de la obligación tributaria, la cual habría surgido ya con el acaecimiento del hecho imponible, consecuencia de la incidencia de la norma tributaria.

Para quienes defienden el carácter constitutivo de la determinación, no es suficiente que se dé la incidencia de la norma tributaria para el nacimiento de la obligación tributaria, siendo necesario un acto expreso que establezca la existencia de dicha obligación y que precise su monto, por lo que mientras no se produzca la determinación, la obligación tributaria no habrá nacido.

De otro lado, para quienes defienden la postura del carácter declarativo de la determinación, la obligación tributaria nace al producirse el hecho imponible, siendo la determinación únicamente la plasmación de algo ya existente, siendo así la función de la determinación el declarar y precisar el monto de la obligación, más no condiciona el nacimiento de la misma.

La antes citada Ordenanza Tributaria Alemana, al señalar que los créditos derivados de la obligación tributaria nacen cuando se realiza el supuesto de hecho al que la ley vincule el deber de prestación, reconoce a la determinación su eficacia declarativa y no constitutiva.

De otro lado, según se desprende del artículo $37^{\circ}$ del Modelo de Código Tributario para América Latina, el mismo se adhiere a esta postura, al señalar que "El hecho generador es el presupuesto, de naturaleza jurídica o económica, establecido por ley para tipificar el tributo y cuya realización origina el nacimiento de la obligación.”

Existe una tercera postura respecto al tema analizado, según la cual si bien la obligación tributaria nace al producirse el hecho imponible, el crédito tributario recién nacerá con la determinación; sin embargo, concordamos con Sáenz Rabanal (1996, p. 
107) cuando señala lo erróneo dicha posición, al reconocer la posibilidad de la existencia de una deuda carente sustancialmente de crédito.

En nuestra opinión, la determinación tiene naturaleza declarativa y no constitutiva, en tanto que como se ha señalado, la obligación tributaria nace con la subsunción de un hecho de la realidad (hecho imponible), con el supuesto de la norma tributaria previamente aprobado (hipótesis de incidencia); por tanto, la determinación es el reconocimiento formal de una obligación que ya existe, que se configuró con la configuración del hecho imponible en la realidad.

Nuestra legislación ha tomado partido por el carácter declarativo de la determinación, en tanto que según lo dispuesto por el artículo $2^{\circ}$ del Código Tributario previamente citado, el nacimiento de la obligación tributaria se produce cuando se realiza el hecho previsto en la ley como generador de dicha obligación, no siendo necesario a tales efectos, esto es, a efectos del nacimiento de la referida obligación tributaria, que se produzca la determinación de la misma.

Otro punto a tratar gira en torno a establecer si la determinación califica como un procedimiento administrativo o como un acto jurídico o administrativo. La posición que la considera como un procedimiento administrativo, parte del desarrollo teórico efectuado por Jarach (1999) respecto al carácter jurisdiccional de la determinación tributaria, negando que la misma tenga la naturaleza de acto administrativo. Según el referido autor, su postura se basa en los siguientes fundamentos:

(...) la autoridad encargada por la ley de efectuar la determinación de la obligación tributaria no tiene facultades discrecionales para determinar o no las obligaciones tributarias. Una vez reconocida la existencia en el mundo fáctico de un hecho imponible en sus diferentes aspectos o elementos constitutivos, la administración tiene el derecho pero también la obligación de determinar la obligación tributaria correspondiente. (p. 431)

Sin embargo, el referido concepto ha sido fuertemente rebatido, fundamentalmente por considerarse que existe jurisdicción únicamente cuando nos encontramos frente a un debate contencioso, esto es, para que exista jurisdicción debe existir una autoridad jurisdiccional por encima de las partes, siendo que en la determinación de la obligación tributaria no existe tal órgano, siendo la Administración una de las partes. 
En lado opuesto se encuentran quienes consideran a la determinación como un acto de carácter administrativo, en tanto se constituye como una manifestación de voluntad de un órgano del Estado, la cual se enmarca dentro de los parámetros establecidos por una norma legal.

Al respecto, Bravo Cucci (2010) ha señalado que:

(...) ha definido la determinación como el acto jurídico por el que se define la situación jurídica de un sujeto a consecuencia de la aplicación del tributo (...) o del goce de un beneficio, de tal suerte que: a) si es efectuada por el sujeto pasivo es un acto jurídico de reconocimiento de su situación jurídico-tributaria realizado ante la Administración, y b) si es realizada por la Administración Tributaria tiene la naturaleza de acto jurídico administrativo. (p. 348)

De nuestra parte, y no obstante que el artículo $59^{\circ}$ de nuestro Código Tributario hace referencia al acto de determinación de la obligación tributaria, consideramos que la determinación tributaria parte de un procedimiento que desemboca en un acto administrativo, el cual si bien se constituye en un pronunciamiento de la administración respecto de una situación jurídica, es evidente que el mismo es conclusión de una serie de actos, esto es, de un procedimiento. Esto es por demás evidente en el caso de las determinaciones efectuadas por la Administración, pero no así cuando ésta acepta la determinación efectuada por el contribuyente, caso en el cual no se detiene a juzgar la cuantía de la obligación tributaria.

Una vez establecidos los conceptos básicos en torno a lo que entendemos como determinación de la obligación tributaria, pasamos a desarrollar los tipos o formas de determinación que podemos encontrar, ya sea sobre la base del sujeto que la efectúa, o considerando la base sobre la cual se realiza.

En cuanto al sujeto que la efectúa, por lo general la doctrina ha considerado tres tipos de determinación, una primera efectuada por el sujeto pasivo o autodeterminación, otra practicada por la Administración o determinación de oficio, y una tercera conocida como determinación mixta.

a) La autodeterminación.- Es aquella realizada por el sujeto pasivo de la obligación tributaria, en su calidad de contribuyente o responsable, o de las personas que ejerzan su representación. Al respecto, de acuerdo a lo señalado por el numeral 1 
del artículo $60^{\circ}$ del Código Tributario, la determinación de la obligación tributaria se inicia por acto o declaración del deudor tributario.

Cabe señalar que según considera tanto la doctrina como la legislación comparada en la actualidad, lo que se busca es el cumplimiento espontaneo por parte del sujeto pasivo, de las obligaciones y deberes que viene impuestos por la normatividad tributaria, lo cual no descarta la intervención de la Administración Tributaria a efectos de asegurar el cumplimiento efectivo de dichos deberes y obligaciones, o en todo caso para ajustarlos a una forma y tiempo de pago determinados.

La autodeterminación es efectuada a través de las declaraciones juradas presentadas por el sujeto pasivo (contribuyente o responsable), teniendo la Administración Tributaria posibilidades de verificación y rectificación, lo cual se aprecia del artículo $61^{\circ}$ del Código Tributario, según el cual la determinación de la obligación tributaria efectuada por el deudor tributario, se encontrará sujeta a la fiscalización o verificación por la Administración Tributaria.

Mediante la declaración jurada, el sujeto pasivo transmite información a la Administración Tributaria, transmisión la cual puede realizarse por vía física o virtual, tal como se verá más adelante.

La declaración presentada por el deudor tributario, la cual se presume como jurada sin admitir prueba en contrario según lo dispuesto en el último párrafo del numeral 88.1 del artículo $88^{\circ}$ del Código Tributario, puede contener errores que podrían ocasionar que la determinación no se encuentre conforme con la situación jurídica con la que se corresponde, siendo así, las legislaciones prevén que luego de presentada la declaración, la misma podrá ser objeto de modificación, ya sea por parte del propio sujeto pasivo o por parte de la Administración. Al respecto, nuestro Código Tributario establece que tales declaraciones podrán ser sustituidas dentro del plazo de presentación de la misma, vencido el cual podrá presentarse una declaración rectificatoria, la cual surtirá efectos con su presentación siempre que determinen igual o mayor obligación; en caso contrario, surtirá efectos si en un plazo de 45 (cuarenta y cinco) días hábiles siguientes a la presentación de la declaración rectificatoria, la Administración Tributaria no emitiera pronunciamiento sobre la veracidad y exactitud de los datos contenidos en 
dicha declaración rectificatoria, sin perjuicio de la facultad de la Administración Tributaria de efectuar la verificación o fiscalización posterior.

Tal como se aprecia, en la determinación por el sujeto pasivo no existe pronunciamiento alguno de la Administración Tributaria sobre el importe de la obligación, lo cual no impide que sea considerada como una determinación, tal como lo considera el Código Tributario en el ya citado artículo $59^{\circ}$.

b) Determinación de oficio.- Es la determinación practicada por el sujeto activo de la obligación tributaria, o por su Administración Tributaria de ser el caso, la cual despliega sus facultades a efectos de verificar la realización del hecho imponible, identificar al deudor tributario, así como señalar la base imponible y la cuantía del tributo; todo lo cual es realizado a través del procedimiento de fiscalización.

Nuestra legislación establece en el numeral 2 del artículo $60^{\circ}$ del Código Tributario, que la determinación de la obligación tributaria puede ser iniciada también por la Administración Tributaria, ya sea por propia iniciativa o por denuncia de terceros; en tanto que el artículo $61^{\circ}$ del referido cuerpo legal, dispone que la determinación de la obligación tributaria efectuada por el sujeto pasivo, se encuentra sujeta a la verificación o fiscalización por la Administración Tributaria.

Podemos concluir en lo que respecta a la determinación de oficio, que la misma procederá cuando no exista determinación del sujeto pasivo por no haber presentado declaración jurada, o en caso haberla presentado, la misma sea objetada por la Administración. La determinación de oficio se realiza, como regla general, tomando como base los datos e información suministrada por el deudor tributario, lo cual no impide que la Administración proceda a determinar la obligación incluso en los casos en que éste no hubiera presentado información alguna, lo cual significa que la Administración, puede modificar la determinación efectuada por el contribuyente a través de una nueva determinación, o puede establecer una determinación que supla la que el contribuyente debió preparar y presentar.

El resultado de la labor de determinación de la Administración, deberá ser comunicada al deudor tributario a través de la resolución de determinación correspondiente, tal como se desprende de lo dispuesto en el artículo $76^{\circ}$ del Código Tributario. 
Es claro así pues, que la determinación efectuada por el sujeto activo de la obligación tributaria, se verá materializada en un acto administrativo concreto, como lo es la resolución de determinación, acto el cual hasta antes de la modificación dispuesta mediante Decreto Legislativo $\mathrm{N}^{\circ} 1113$, se consideraba como único, integral y definitivo, idea la cual fue ratificada mediante Acuerdo de Sala Plena del Tribunal Fiscal $N^{\circ} 25-2005$, en la cual se hacía referencia a la inmutabilidad de las resoluciones no impugnadas, salvo los casos de excepción previstos en el artículo $108^{\circ}$ del Código Tributario, por lo que una vez la determinación se concretizaba en una resolución de determinación, culminaba la potestad de la Administración para determinar la deuda tributaria del contribuyente, habiendo sido recogido dicho criterio en diversas Resoluciones del Tribunal Fiscal, tales como las N 4941-2-2006, 2647-1-2009, 37181-2010, entre otras; no obstante lo cual, con la modificación establecida por el precitado decreto legislativo dicho criterio no se mantiene en toda su amplitud, al permitirse la posibilidad de efectuar determinaciones parciales por parte de la SUNAT

La determinación de oficio podrá ser efectuada por la Administración Tributaria ya sea sobre base cierta o sobre base presunta, existiendo determinación sobre base cierta, cuando la Administración cuenta con todos los elementos relacionados con el hecho imponible, no solo respecto a la existencia del mismo, sino también a su magnitud. Así, el numeral 2 del artículo $63^{\circ}$ de nuestro Código Tributario dispone que la Administración podrá determinar la obligación tributaria sobre base cierta, tomando en cuenta los elementos existentes que permitan conocer en forma directa el hecho generador de la obligación tributaria y la cuantía de la misma.

En cuanto la determinación sobre base presunta, la misma se da en los casos en los cuales la Administración no cuenta con los elementos necesarios para efectuar una determinación sobre base cierta, por lo cual puede recurrir a presunciones o indicios. Nuestro Código Tributario establece al respecto en el numeral del citado artículo $63^{\circ}$, que dicha determinación se llevará a cabo en mérito a los hechos y circunstancias que, por relación normal con el hecho generador de la obligación tributaria (hecho imponible), permitan establecer la existencia y la cuantía de la obligación.

c) Determinación mixta.- Es aquella que se realiza mediante la acción coordinada de la administración y el contribuyente, quienes por la vía transaccional proceden a determinar la obligación tributaria. Es un tipo de determinación muy poco 
utilizada, sobre todo en países como Italia o Suiza, no existiendo dicha posibilidad en nuestro país.

Una vez expuestos los temas conceptuales previamente desarrollados, corresponde analizar el tema en sí de la Orden de Pago, con el fin de establecer su naturaleza, y así poder verificar si la misma se encuentra acorde con lo dispuesto por la legislación nacional respecto a la emisión de dichos valores.

\subsection{La Orden de Pago y su naturaleza}

Al respecto, es pertinente partir de lo dispuesto por el Código Tributario en relación a la orden de pago:

\section{Artículo $78^{\circ}$.- Orden de Pago}

La Orden de Pago es el acto en virtud del cual la Administración exige al deudor tributario la cancelación de la deuda tributaria, sin necesidad de emitirse previamente la Resolución de Determinación, en los casos siguientes:

1. Por tributos autoliquidados por el deudor tributario.

2. Por anticipos o pagos a cuenta, exigidos de acuerdo a ley.

3. Por tributos derivados de errores materiales de redacción o de cálculo en las declaraciones, comunicaciones o documentos de pago. Para determinar el monto de la Orden de Pago, la Administración Tributaria considerará la base imponible del período, los saldos a favor o créditos declarados en períodos anteriores y los pagos a cuenta realizados en estos últimos.

Para efectos de este numeral, también se considera el error originado por el deudor tributario al consignar una tasa inexistente.

4. Tratándose de deudores tributarios que no declararon ni determinaron su obligación o que habiendo declarado no efectuaron la determinación de la misma, por uno o más períodos tributarios, previo requerimiento para que realicen la declaración y determinación omitidas y abonen los tributos correspondientes, dentro de un término de tres (3) días hábiles, de acuerdo al procedimiento establecido en el artículo siguiente, sin perjuicio que la Administración Tributaria pueda optar por practicarles una determinación de oficio.

5. Cuando la Administración Tributaria realice una verificación de los libros y registros contables del deudor tributario y encuentre tributos no pagados. 
Las Órdenes de Pago que emita la Administración, en lo pertinente, tendrán los mismos requisitos formales que la Resolución de Determinación, a excepción de los motivos determinantes del reparo u observación.

Teniendo en cuenta lo establecido por el artículo $78^{\circ}$ del Código Tributario, podemos definir a la orden de pago (denominadas antiguamente como giro provisional), como el acto en virtud del cual la Administración exige al deudor tributario la cancelación de la deuda tributaria, sin necesidad de emitirse previamente la resolución de determinación. De la definición señalada podemos extraer una primera conclusión, que si bien estamos ante un acto administrativo emitido por la Administración Tributaria, no es el resultado de una determinación de oficio.

Iannacone (2001) nos da una definición de orden de pago:

Las órdenes de pago son los actos de la Administración Tributaria en virtud de los cuales se exige al deudor tributario el cumplimiento inmediato de una obligación principal, es decir, de pagar. Son documentos de orden inmediato que se aplican cuando la deuda es certera (...). (p. 31)

Nava Tolentino (2007) al referirse a la orden de pago señala que:

(...) en este acto la Administración Tributaria -bajo el principio de Presunción de Veracidad- considera las bases imponibles y datos consignados en la declaración jurada mensual del contribuyente, y ante su falta de pago emite la OP sin cuestionar el fondo de la declaración hacha por el deudor tributario. (p. 24)

Así, tenemos que la Orden de Pago es un mandato de pago, un acto por el cual la Administración reclama al deudor tributario la cancelación de una deuda exigible, acto el cual contiene la exigencia al deudor tributario, del pago de una deuda tributaria cierta y cuya cuantía se conoce con certeza, por lo que son plenamente exigibles por la Administración.

La Orden de Pago es por su propia naturaleza un acto distinto a la resolución de determinación, en tanto que para su emisión no se requiere la realización de un procedimiento de fiscalización, bastando a tales efectos fundamentalmente la simple constatación de la existencia de una deuda impaga cierta, no teniendo como sustento la existencia de reparo alguno, siendo a lo sumo producto de una simple constatación de los libros y registros contables, e incluso de la simple verificación en los sistemas de la 
Administración de las declaraciones juradas presentadas por los contribuyentes, y en las cuales se reconozca la existencia de una obligación tributaria exigible y no cancelada.

En cuanto a la distinta naturaleza de la Orden de Pago respecto de la resolución de determinación, Talledo Mazú (2013) indica que:

La Orden de Pago (Giro provisional en el Código anterior) se diferencia de la determinación (acotación) en su forma de producción y materia. No nace de una fiscalización sino de la mera constatación de una obligación exigible. Tiene como materia una obligación de cuya cuantía hay certeza. La Orden de Pago es así el requerimiento de pago de una obligación cierta, mientras que la determinación es simplemente la liquidación e imputación de una deuda que puede ser discutida por el contribuyente en cuanto a su existencia y cuantía. (p. 110.12.A)

Al respecto, el Tribunal Fiscal ha señalado en el Acuerdo de Sala Plena $N^{\circ} 2015-07$ de 12 de junio de 2015, que la orden de pago constituye un requerimiento de pago de una obligación cierta, diferenciándola así de la determinación realizado al amparo del inciso b) del artículo $56^{\circ}$ del Código Tributario.

Debe precisarse asimismo, que tal como se señala en el último párrafo del citado artículo $78^{\circ}$ del Código Tributario, las órdenes de pago deben contener los requisitos formales que para su emisión se exigen a la resolución de determinación, con excepción de la fundamentación de los motivos determinantes del reparo, lo cual es por demás obvio al no provenir dicho acto administrativo de un procedimiento de fiscalización.

La orden de pago califica como un acto administrativo debido a los efectos que tiene hacia el administrado, por el cual se reconocen derechos a favor del fisco, constituyéndose asimismo como un valor, en razón al carácter que le da la ley, expresando una acreencia que en caso no ser cancelada se encontrará expedita para ser ejecutada por las vías administrativas sumarias, tema este respecto al cual volveremos posteriormente.

De la revisión de lo dispuesto por el citado artículo $78^{\circ}$ del Código Tributario, se aprecia la existencia de una serie de supuestos en los cuales procede la emisión de una orden de pago, los cuales pueden ser agrupados en dos grupos generales.

En los supuestos señalados en los numerales 1 a 3 , estamos frente a casos en cuales ha existido una previa determinación y liquidación del tributo (anticipo o pago a cuenta) efectuada por el deudor tributario, supuestos en los cuales es claro que la orden 
de pago debiera implicar una mera exigencia de pago; no obstante lo cual, existe un problema álgido en torno a las órdenes de pago emitidas por el numeral 3, cuya emisión muchas veces no corresponde a errores de redacción o de cálculo en las determinaciones efectuadas, como desarrollaremos con amplitud en el siguiente capítulo.

En los restantes casos estamos frente a la ausencia de autodeterminación, lo cual obliga a la Administración a efectuar la liquidación del tributo. La orden de pago encuentra su sustento en dichos casos, en los datos consignados por el propio contribuyente o que se derivan de sus declaraciones o libros y registros contables, no implicando procedimiento de determinación alguno.

En el caso de órdenes de pago emitidas por tributos autoliquidados (auto determinados) por el deudor tributario, la emisión de las mismas se da cuando el propio contribuyente determina y declara un tributo a pagar, pero no abona o paga suma alguna por dicha deuda. Se tiene así que la emisión de una orden de pago en el presente caso, puede darse no solo por el total del tributo determinado y no pagado por el deudor tributario, sino también en el caso de presentarse un saldo no pago.

Debe tenerse presente que de no existir obligación por parte del deudor tributario de hacer autodeterminación, autoliquidación o simplemente declaración, no existirá tributo o deuda autoliquidada, por lo que no corresponderá de ninguna manera la emisión de una orden de pago bajo el supuesto bajo análisis. Al respecto, se tiene que en el caso de las tasas por servicios públicos o arbitrios municipales, hasta hace algunos años las municipalidades vinieron emitiendo órdenes de pago por deudas correspondientes a dichos tributos, por lo que el Tribunal Fiscal estableció en reiteradas resoluciones, tales como las $\mathrm{N}^{\circ}$ 2687-3-2004, 5471-1-2004, 1215172007 y 1737-72008, entre otras, que al no ser los arbitrios municipales susceptibles de autoliquidarse por el deudor tributario, para efectuarse su cobro debe emitirse una resolución de determinación y no una orden de pago. Si bien es correcto el criterio sentado por el tribunal al establecer que no procede la emisión de una orden de pago en el caso de Arbitrios Municipales, el criterio del Tribunal Fiscal flaquea al no sustentar porqué considera que en dicho caso se debe emitir una resolución de determinación, ya que por lo general no existe procedimiento de fiscalización alguna en dichos casos. 
Si bien esta tipo de órdenes de pago tiene su sustento en la determinación efectuada por el deudor tributario, la emisión de dicho valor por parte de la Administración no convalidad la determinación efectuada, en tanto que tal como se ha señalado, de acuerdo con lo dispuesto por los artículos $61^{\circ}$ y $88^{\circ}$ del Código Tributario, la determinación efectuada por el deudor tributario, y por ende la declaración presentada a tales efectos, se encuentra sujeta a verificación o fiscalización por la Administración Tributaria, quien podrá modificarla de constatar omisión o inexactitud en la información proporcionada.

Respecto de la órdenes de pago relacionadas con errores materiales de redacción o de cálculo, tal como hemos señalado previamente las mismas serán objeto de un análisis pormenorizado en el capítulo siguiente, bastando adelantar que lo dispuesto en el numeral 3 del artículo $78^{\circ}$ del Código Tributario, ha derivado en un cajón de sastre, del cual han derivado no solo perjuicios para los contribuyentes, sino en una serie de criterios contradictorios en la jurisprudencia del Tribunal Fiscal.

Tal como se ha señalado, existe la posibilidad que la administración emita órdenes de pago por una deuda constatada con la información anotada en los libros y registros contables del deudor tributario, resultado de comparar con lo declarado por el deudor tributario, vía verificación o compulsa, y no como resultado de una fiscalización. Tal como se señala, la emisión de dicho tipo de órdenes de pago no implica el examen o evaluación de libros o registros contables ni de la documentación sustentatoria de los mismos ni de las operaciones realizadas, lo cual es propio de un procedimiento de fiscalización, sino la simple constatación del monto que se adeuda en base a la información consignada en los mencionados registros, la cual puede ser comparada con las declaraciones juradas presentadas por el contribuyente, tal como ha señalado el Tribunal Fiscal en la Resolución N 121-4-2001.

Luego de haber efectuado el análisis de una serie de conceptos relacionados directa o indirectamente con la figura de la orden de pago, así como de lo dispuesto al respecto por la legislación nacional, podemos concluir que la orden de pago tiene la naturaleza de un acto administrativo, propio de toda Administración Tributaria, por el cual exige el pago respecto de tributos liquidados por el deudor tributario o responsable a través de una declaración jurada o, en los casos que no existe la referida liquidación, la misma será efectuada por la propia Administración, pero sobre la base de los datos consignados u obtenidos del propio deudor tributario y no cuestionados, no existiendo 
así labor de determinación alguna por parte de la Administración, lo que es más propio de una resolución de determinación.

Consideramos que la idea central en torno a la cual gira la naturaleza de la orden de pago, está dada por el hecho de la ausencia de acto de determinación alguna por parte de la Administración Tributaria, de existir así el más mínimo acto de determinación vinculado a la emisión de una orden de pago, ya sea de manera directa o indirecta, determinará que el referido acto pierda su naturaleza, con las implicancias que lo mismo acarreará al deudor tributario, en vista principalmente a la ejecutoriedad casi inmediata de toda orden de pago. 


\section{CAPÍTULO II: EJECUTORIEDAD DE LA ORDEN PAGO, SOLVE ET REPETE Y RECLAMACIÓN}

A continuación, trataremos el tema de la ejecutoriedad de la orden de pago, y los problemas que puede acarrear a un contribuyente la notificación de un acto administrativo de dicha naturaleza, situación que se ha complicado en virtud a criterios jurisprudenciales del Tribunal Fiscal. Afrontaremos asimismo el tema de la queja y la reclamación contra órdenes de pago, y la casi indefensión en la que se encuentran los contribuyentes en la actualidad.

\subsection{Ejecutoriedad de la orden de pago}

Partamos del concepto de recaudación, el que podemos ver como el conjunto de actos de la Administración Tributaria y de los sujetos pasivos que constituyen una exigencia, recepción o entrega de dinero o bienes, por concepto del pago de una obligación tributaria. Así, Calvo Ortega (2000) al referirse al procedimiento de recaudación, señala que "La recaudación es una actividad administrativa que tiene por finalidad hacer efectiva la obligación tributaria. Mediante ella el acreedor tributario ve satisfecho su crédito en la forma establecida por ley." (p. 332).

Por lo general, la recaudación implica un acto jurídico para el sujeto pasivo cuyos efectos se encuentran establecidos por ley, y por el cual es el propio sujeto pasivo quien hace efectiva la obligación tributaria, caso contrario, será la Administración Tributaria quien deberá hacer efectiva dicha obligación, tenemos así que en principio, es el propio deudor tributario quien por mutuo propio, debería efectuar la cancelación de la obligación. Así tenemos que el pago del impuesto por el deudor, sin coerción alguna y de manera voluntaria, corresponde a la conclusión natural del procedimiento, por lo que al cumplirse la obligación de pago de tal manera, la fiscalización y el cobro pueden incluso no llegar a realizarse.

Podemos concluir así, que la cobranza de la deuda tributaria por parte de la Administración, es subsidiaria al pago que debe efectuar el deudor tributario, lo cual 
dependerá por lo general, del grado de conciencia de pago de tributos que exista en una determinada sociedad.

En cuanto a la facultad de que goza la Administración para hacer efectiva de manera directa los actos de cobró de la deuda tributaria, la misma constituye una prerrogativa de la cual se encuentra investida, la que si bien viene siendo cuestionada en razón de su incompatibilidad con el Estado de Derecho, continua siendo una facultad esencial de la Administración, pesando más los fundamentos que la justifican, como son la presunción de legitimidad y el interés general, sumándose a estos otros más propios del derecho tributario, como lo son el principio de solidaridad o el de contribución al sostenimiento de los gastos públicos en virtud a la capacidad económica.

En lo que respecta a la referida facultad con que cuenta la Administración en general, Dromi (1995) señala que:

(...) Partiendo de la concepción de que el poder del Estado es uno y único, no podemos negar a la Administración la capacidad para obtener el cumplimiento de sus propios actos, sin necesidad de que el órgano judicial reconozca su derecho y habilite a ejecutarlos.

(...) La ejecutoriedad es un elemento inescindible del poder. La ejecutoriedad es un carácter esencial de la actividad administrativa, que se manifiesta en algunas categorías o clases de actos y en otros no, dependiendo esto último del objeto y la finalidad del acto administrativo. (p. 230)

La precitada facultad implica que la Administración proceda a la ejecución del acto administrativo por sus propios medios, sin la necesidad de recurrir a tales efectos al Poder Judicial, para lo cual se encuentra dotada de facultades coercitivas y ejecutivas a través de un proceso sumarísimo de ejecución del acto, en el caso peruano el procedimiento de cobranza coactiva.

Dicha facultad de ejecutoriedad o autotutela se plasma en un acto administrativo de coerción y de ejecución, sobre la base del ius imperium con el que se encuentra investida la Administración. El ejercicio de dicha facultad por parte de la Administración, no implica de manera alguna que la Administración cuenta con plena libertad para vulnerar los derechos fundamentales de los contribuyentes, siendo el propio Tribunal Constitucional quien lo ha señalado de manera expresa. Así, tenemos lo expuesto por dicho órgano colegiado en la Sentencia $\mathrm{N}^{\circ} 15-2005-\mathrm{PI} / \mathrm{TC}$ : 
(...) la Administración Pública tiene a capacidad para proteger directamente sus intereses, pudiendo incluso exigir por sí mismo el cumplimiento de sus actos. Sin embargo, esta facultad de autotutela de la Administración Pública de ejecutar sus propias resoluciones, sustentada en los principios de presunción de legitimidad y de ejecución de las decisiones administrativas, implica la tutela de los derechos fundamentales de los administrados que pueden verse amenazados o vulnerados por la actividad de la Administración, como son los derechos al debido procedimiento y a la tutela judicial efectiva (...).

Al hablar sobre el procedimiento de ejecución, Calvo Ortega (2000) nos presenta algunas consideraciones importantes, al señalar que:

Toda obligación tiene como objetivo su cumplimiento y el derecho ordena toda su estructura para su realización; y ello en interés de los propios sujetos y de la justicia que debe presidir las relaciones sociales. Esta consideración es más importante, si cabe, en la obligación tributaria teniendo en cuenta su carácter público, su indisponibilidad por los sujetos activo y pasivo y su contribución esencial a la realización de una justicia determinada (la fiscal) que afecta a la totalidad de los ciudadanos. Todo ello lleva a la conclusión del cumplimiento coactivo de las obligaciones y, por lo que aquí interesa, del pago forzoso de los tributos (...). (p. 347)

Podemos definir a la cobranza como todas aquellas actividades realizadas por la Administración para asegurar el pago no sólo de los tributos, sino también de las sanciones, intereses, multas y cualquier otro monto accesorio por medio del uso de procedimientos administrativos de carácter coactivo, cuando el pago de los mismos no se ha efectuado en forma oportuna y/o espontanea.

El Código Tributario establece en su artículo $114^{\circ}$, en lo que respecta a la cobranza coactiva como facultad de la Administración Tributaria, que la cobranza de las deudas tributarias es facultad de la Administración Tributaria, se ejerce a través del Ejecutor Coactivo, quien actuará en el procedimiento de cobranza coactiva con la colaboración de los Auxiliares Coactivos. Debe precisarse que las normas del Código Tributario relacionadas con la cobranza coactiva serán de aplicación cuando el acreedor tributario sea una entidad distinta a los gobiernos locales, caso en el cual serán de aplicación las normas del Texto Único Ordenado de la la Ley $\mathrm{N}^{\circ} 26979$ aprobado por Decreto Supremo $N^{\circ}$ 018-2008-JUS y su reglamento aprobado por Decreto Supremo $N^{\circ}$ 069-2003-EF. 
Asimismo, debe tenerse en cuenta que el Texto Único Ordenado de la Ley del Procedimiento Administrativo General aprobado por decreto Supremo $\mathrm{N}^{\circ}$ 006-2017JUS, define en su artículo $206^{\circ}$ a la ejecución coactiva como el medio a través del cual una entidad puede procurarse la ejecución de un obligación de dar, hacer o no hacer, facultad que deberá efectuarse respetando el principio de razonabilidad, esto es, que las decisiones de la autoridad administrativa deben adoptarse manteniendo la debida proporción entre los medios a emplear y los fines públicos que deba tutelar a fin de que respondan a lo estrictamente necesario para la satisfacción de lo cometido, tal como dispone el numeral 1.4 del artículo IV de la referida ley.

Al respecto, Juan Carlo Morón (2011) señala que:

La condición para que opere esta modalidad de ejecución es que se trate de una deuda originada en una relación jurídica de Derecho Público, esto es, que la percepción se funde en la potestad de imperio inherente al poder público y no en la realización de operaciones de derecho común (civil o empresarial del Estado), como puede ser adeudos de origen contractual, indemnizaciones, en cuyo caso obligatoriamente el fuero natural es el jurisdiccional. Las deudas que más comúnmente son materia de cobranza en la vía coactiva son las tributarias, multas, reversión de pagos indebidos y sanciones.

Estructuralmente se trata de un procedimiento expeditivo a cargo de la propia Administración y análogo al proceso de ejecución para las deudas civiles o mercantiles que se desarrolla ante el Poder Judicial. (p. 561 y 562)

Asimismo, tenemos lo señalado por Jorge Danos (1995), para el cual el procedimiento de cobranza coactiva constituye “(...) una manifestación clara del principio de autotutela en cuya virtud las entidades de la Administración Pública ostentan la prerrogativa para ejecutar por sí mismas sus propios actos administrativos sin intervención judicial previa.” (p. 43)

Podemos concluir sobre la base de lo antes señalado, que la cobranza coactiva de las deudas tributarias se constituye como una facultad de la Administración Tributaria, que tiene sustento en la naturaleza pública del tributo, mediante la cual exige coactivamente a los deudores tributarios la satisfacción de sus pretensiones, a través de la cancelación de las deudas que se encontraran pendientes.

Ahora bien, el Código Tributario establece en su artículo $115^{\circ}$, las deudas que se consideran exigibles, y que por lo tanto dan lugar a las acciones de coerción para su cobranza: 
a) La establecida mediante Resolución de Determinación o de Multa o la contenida en la Resolución de pérdida del fraccionamiento notificada por la Administración y no reclamada en el plazo de ley. En el supuesto de la resolución de pérdida de fraccionamiento se mantendrá la condición de deuda exigible si efectuándose la reclamación dentro del plazo, no se continúa con el pago de las cuotas de fraccionamiento.

b) La establecida mediante Resolución de Determinación o de Multa reclamadas fuera del plazo establecido para la interposición del recurso, siempre que no se cumpla con presentar la Carta Fianza respectiva conforme con lo dispuesto en el Artículo $137^{\circ}$.

c) La establecida por Resolución no apelada en el plazo de ley, o apelada fuera del plazo legal, siempre que no se cumpla con presentar la Carta Fianza respectiva conforme con lo dispuesto en el Artículo $146^{\circ}$, o la establecida por Resolución del Tribunal Fiscal.

d) La que conste en Orden de Pago notificada conforme a ley.

e) Las costas y los gastos en que la Administración hubiera incurrido en el Procedimiento de Cobranza Coactiva, y en la aplicación de sanciones no pecuniarias de conformidad con las normas vigentes.

Por su parte, según lo establecido por el numeral 25.1 del artículo $25^{\circ}$ de la Ley $\mathrm{N}^{\circ}$ $26979^{4}$, aplicable al caso de procedimientos de cobranza coactiva de obligaciones tributarias de los gobiernos locales, se considera deuda exigible a:

a) La establecida mediante Resolución de Determinación o de Multa, emitida por la entidad conforme a ley, debidamente notificada y no reclamada en el plazo de ley.

b) La establecida por resolución debidamente notificada y no apelada en el plazo de ley, o por Resolución del Tribunal Fiscal.

c) Aquella constituida por las cuotas de amortización de la deuda tributaria materia de aplazamiento y/o fraccionamiento pendientes de pago, cuando se incumplan las condiciones bajo las cuales se otorgó ese beneficio, siempre y

\footnotetext{
${ }^{4}$ De acuerdo con lo estipulado en el artículo $24^{\circ}$ de la referida Ley $\mathrm{N}^{\circ} 26979$, las citadas normas se aplicarán de manera exclusiva al procedimiento de cobranza correspondiente obligaciones tributarias a cargo de los Gobiernos Locales.
} 
cuando se haya cumplido con notificar al deudor la resolución que declare la pérdida del beneficio de fraccionamiento y no se hubiera interpuesto recurso impugnatorio dentro del plazo de ley.

d) La que conste en una Orden de Pago emitida conforme a ley y debidamente notificada, de conformidad con las disposiciones de la materia del Código Tributario. 5

Tal como señala Danos (1995), se deben considerar como deudas exigibles coactivamente:

(...) aquellas deudas cuya existencia está amparada por un acto administrativo válido que determine el importe de lo debido y que haya sido debidamente puesto en conocimiento del particular para darle la posibilidad de proceder al pago voluntario de la deuda o, en caso de disconformidad para permitirle la impugnación de la legalidad de dicho acto administrativo. (p. 35 y 36 )

Asimismo, Sotelo (1996) indica que "La actuación administrativa garantiza o asegura que las deudas tributarias que serán llevadas al procedimiento de ejecución forzada, son líquidas y, luego, que el deudor tributario tiene cabal conocimiento de su existencia y de su estado de insoluta." (p. 43)

Del artículo $115^{\circ}$ del Código Tributario y el numeral 25.1 del artículo $25^{\circ}$ de la Ley del Procedimiento de Ejecución Coactiva, se aprecia que se consideran como exigibles coactivamente las deudas impagas que consten en actos administrativos que tengan la calidad de consentidos al haber vencido el plazo para su impugnación o que constituyen pronunciamiento de la última instancia administrativa, o que reflejen la autodeterminación efectuada por el deudor tributario como son las órdenes de pago, casos en los cuales ya no debería existir controversia alguna o en principio nunca existió, siendo una excepción el caso de las costas y gastos.

Tal como hemos señalado previamente, la orden de pago tiene por naturaleza la calidad de acto administrativo, y a diferencia de la resolución de determinación o resolución de multa, tiene el carácter de deuda exigible coactivamente desde su notificación válidamente realizada, en tanto que proviene de una autodeterminación

\footnotetext{
${ }^{5}$ Es importante señalar que de conformidad con lo dispuesto por el numeral 25.2 del artículo $25^{\circ}$ en cuestión, la Administración tributaria de los Gobiernos Locales únicamente emitirá órdenes de pago en los casos establecidos en los numerales 1 y 3 del artículo $78^{\circ}$ del Código Tributario, debiendo emitir en los demás supuestos resoluciones de determinación.
} 
efectuada por el mismo deudor tributario y que no ha sido pagada; por tal motivo, en el caso de las órdenes de pago no es requisito para que la deuda contenida en las mismas sea considerada deuda tributaria exigible coactivamente, que haya vencido el plazo de veinte días hábiles para impugnarlas vía reclamación, en tanto que a menos que existan circunstancias que evidencien su manifiesta improcedencia, las órdenes de pago responden a un acto previo del propio deudor.

Así, podemos concluir que el carácter de ejecutable coactivamente que cuentan las órdenes de pago por el solo hecho de haber sido notificadas de acuerdo a ley, proviene de la misma naturaleza de dicho acto administrativo.

En tal sentido, el Tribunal Fiscal ha señalado en el precitado Acuerdo de Sala Plena $\mathrm{N}^{\circ}$ 2015-2007, que sobre la base de la característica de la orden de pago de tratarse de un acto de requerimiento y no de uno de determinación:

(...) se desprenden consecuencias como son la obligación de efectuar el pago previo de la orden de pago como condición para admitir a trámite su reclamación y el hecho de que la deuda contenida en una orden de pago adquiera calidad de exigible coactivamente a partir del día siguiente de su notificación realizada conforme a ley, a diferencia de la deuda contenida en resoluciones de determinación y de multa, la cual adquiere dicha condición una vez ha transcurrido el plazo previsto por el Código Tributario para impugnar sin que el deudor tributario haya presentado el recurso de impugnación correspondiente.

Habiendo establecido el carácter de ejecutable con que cuentan las órdenes de pago, lo cual en principio se encuentra acorde con su propia naturaleza, es pertinente abordar el tema de como afrontar las consecuencias de la notificación de una orden de pago, a efectos de evitar la inmediata cobranza de la deuda contenida en la misma.

\subsection{La queja ante Órdenes de Pago}

Si bien como hemos concluido la orden de pago deviene en exigible por su propia naturaleza, se debe tener en cuenta que de acuerdo a lo dispuesto por el numeral 3 del inciso a) del artículo $119^{\circ}$ del Código Tributario, el ejecutor coactivo podrá suspender temporalmente el procedimiento de cobranza coactiva, de manera excepcional, tratándose de órdenes de pago, y cuando medien circunstancias que evidencien que la cobranza podría ser improcedente y siempre que la reclamación se hubiera interpuesto 
dentro de los 20 días hábiles de notificada la orden de pago, debiendo mantenerse la suspensión mientras que la deuda sea exigible de conformidad con lo establecido en el artículo $115^{\circ}$. Asimismo, el numeral 31.2 de la Ley $\mathrm{N}^{\circ} 26979$ establece igualmente que excepcionalmente, tratándose de Órdenes de Pago y cuando medien circunstancias que evidencien que la cobranza pueda ser improcedente, la Entidad debe admitir la reclamación sin pago previo, siempre que ésta sea presentada dentro del plazo de veinte días hábiles siguientes al de la notificación de la Orden de Pago, suspendiendo la cobranza coactiva hasta que la deuda sea exigible coactivamente.

Lo antes señalado surge como consecuencia del ensalzamiento del derecho a la tutela efectiva, así como al ya citado retroceso de la autotutela de la Administración, de donde se desprenden que los deudores tributarios pueden presentar sus impugnaciones con cada vez menos limitaciones. No obstante lo cual, y siendo que la presunción de legalidad es mayor en el caso de las órdenes de pago ya que estamos en principio ante una obligación tributaria que ya ha sido determinada (por lo general) por actos propios del deudor tributario, por lo que la regla antes señalada califica como una excepción, suspensión la cual según considera Spisso (1996) “(...) constituye un significativo instrumento en orden a posibilitar el derecho a la tutela judicial efectiva.” (p. 82)

Ahora bien ¿Cuál es el medio de defensa con el cual cuenta un contribuyente en caso se vea inmerso en procedimiento de cobranza coactiva el cual considera no se encuentra arreglado a ley? En dichos casos cuenta en primer lugar con la queja, la cual según lo dispuesto por el artículo $155^{\circ}$ del Código Tributario, se presenta cuando existan actuaciones o procedimientos que afecten directamente o infrinjan lo establecido en dicho Código, como lo serán las actuaciones o procedimientos de los ejecutores coactivos. De manera más precisa, y para el caso de los Gobiernos Municipales, el numeral 38.1 del artículo $38^{\circ}$ de la Ley $\mathrm{N}^{\circ} 26979$, dispone que el obligado podrá interponer recurso de queja ante el Tribunal Fiscal contra las actuaciones o procedimientos del Ejecutor o Auxiliar que lo afecten directamente e infrinjan lo establecido en dicha ley respecto al cobro de obligaciones tributarias de los gobiernos municipales, debiendo en dicho caso el Tribunal Fiscal resolver dentro de los veinte (20) días hábiles de presentado el recurso, pudiendo ordenar la suspensión del Procedimiento o la suspensión de una o más medidas cautelares. 
Al respecto, podemos citar una serie de pronunciamientos del Tribunal Fiscal relacionados con procedimientos de cobranza coactiva, así tenemos los siguientes fallos:

- 4415-5-2006.- Si la Administración no remite al Tribunal Fiscal las declaraciones juradas que sustentan las órdenes de pago materia de cobranza coactiva a pesar de habérselas solicitado, no acredita que tales valores se ajusten a lo dispuesto por el artículo $78^{\circ}$ del Código Tributario y por tanto que la deuda que contienen sea exigible coactivamente.

- 4735-5-2006.- La Administración no acredita que la deuda tributaria tenga el carácter de exigible coactivamente, cuando no remite los valores en que se sustenta la cobranza ni sus respectivas constancias de notificación.

- 486-4-2007.- La modalidad de notificación por cedulón no se encuentra contemplada en la Ley del Procedimiento Administrativo General, Ley $N^{\circ}$ 27444, por lo que no resulta válida para notificar las resoluciones de cobranza coactiva emitidas por los Gobiernos Locales.

- 01380-1-2006 (Jurisprudencia de Observancia Obligatoria).- Procede que el Tribunal Fiscal en vía de queja se pronuncie sobre la validez de la notificación de los valores y/o resoluciones emitidas por la Administración cuando la deuda tributaria se encuentra en cobranza coactiva.

- 448-5-2007.- La notificación conjunta de la orden de pago y la resolución de ejecución coactiva vulnera el debido procedimiento y el derecho de defensa en sede administrativa según sentencia del Tribunal Constitucional recaída en el Expediente $\mathrm{N}^{\mathrm{o}}$ 3797-2006-PA/TC.

- 00226-Q-2016 (Jurisprudencia de Observancia Obligatoria).- Procede que el Tribunal Fiscal se pronuncie en la vía de queja sobre la prescripción, cuando la deuda tributaria se encuentre en cobranza coactiva, siempre que se deduzca previamente ante el Ejecutor Coactivo y éste, correspondiéndole emitir pronunciamiento, omita hacerlo o deniegue lo solicitado contraviniendo las normas del Código Tributario. El pronunciamiento del Tribunal Fiscal puede estar referido a la prescripción de la acción de la Administración Tributaria para determinar la obligación tributaria, así como sobre la acción para exigir su pago y aplicar sanciones. 
Como podemos apreciar, el Tribunal Fiscal ha venido emitiendo una serie de pronunciamientos, algunos de los cuales con el carácter de jurisprudencia de observancia obligatoria, que han venido delineando un núcleo de defensa de los contribuyentes en el caso de procedimientos coactivos no seguidos de conformidad con la normatividad pertinente.

No obstante lo cual, a fines del año 2010 el Tribunal Fiscal estableció un nuevo criterio de observancia obligatoria mediante la Resolución $N^{\mathbf{o}}$ 1507-5-2010, el cual contrariamente a lo antes señalado, disminuye el ámbito de defensa con el cual cuentan los contribuyentes. Así, mediante la referida resolución se han establecido los siguientes criterios:

i) No procede que en la vía de la queja se evalúe la validez de una orden de pago, según el artículo $78^{\circ}$ del Código Tributario, a efecto de verificar la legalidad de su cobranza coactiva, cuando ésta es iniciada al amparo de dicho código.

ii) No procede que en la vía de la queja se evalúe la existencia de circunstancias que evidencien que la cobranza de una orden de pago podría ser improcedente, al amparo del numeral 3 del inciso a) del artículo $119^{\circ}$ del Código Tributario. Procede que el Tribunal Fiscal ordene la suspensión del procedimiento de cobranza coactiva si con posterioridad a la interposición del recurso de reclamación se hubiera continuado con dicho procedimiento sin que se haya notificado previamente la resolución que declare inadmisible dicha reclamación por no haberse acreditado el pago previo.

iii) Procede que el Tribunal Fiscal en la vía de la queja emita pronunciamiento sobre la legalidad de un procedimiento de cobranza coactiva iniciado al amparo del Código Tributario, cuando el quejoso solicita que se ordene su conclusión y el ejecutor coactivo acredita que éste ha sido suspendido temporalmente.

Son preocupantes principalmente los criterios del Tribunal Fiscal establecidos en la referida resolución, por los cuales se determina la imposibilidad de analizar en vía de queja, si la orden de pago en cobranza ha sido emitida con arreglo a lo dispuesto por el artículo $78^{\circ}$ del Código Tributario, así como la existencia de circunstancias que evidencien que la cobranza podría devenir en improcedente. Los referidos temas así, deberán ser vistos en vía de reclamación, reclamación que deberá ser resuelta por la Administración, y para la cual existe en principio el requisito del pago previo para su admisión como veremos más adelante. 
Según se aprecia de la resolución antes citada, el Tribunal Fiscal considera que la queja no es la vía para cuestionar los actos emitidos por la Administración Tributaria que son susceptibles de serlo a través del procedimiento contencioso tributario regulado por el Código Tributario como ha sido previsto en el caso de la nulidad de los valores que emita la Administración. Así señala que:

En tal sentido, se aprecia que el Código Tributario ha previsto que la declaración de nulidad de los valores emitidos por la Administración Tributaria debe ser solicitada a través del procedimiento contencioso tributario y de producirse dicha declaración, el ejecutor coactivo deberá concluir el procedimiento coactivo. Por consiguiente, al existir una vía expresamente prevista por el ordenamiento para determinar la validez de la orden de pago, no procede que el Tribunal Fiscal se pronuncie al respecto en la vía de la queja, puesto que lo contrario, implicaría que existan dos vías paralelas para cuestionar la validez del referido valor, lo que no tiene amparo legal. ${ }^{6}$

El Tribunal Fiscal parece haber olvidado así que, tal como señala en la misma resolución en cuestión, la queja en cuanto remedio procesal “(...) está dirigida a encauzar la actuación de la Administración Tributaria que afecte o pueda afectar en forma indebida los derechos de los deudores tributarios cuando estos no tengan otra vía para corregir la actuación de la Administración Tributaria (...)”

Consideramos así que los criterios establecidos en la Resolución del Tribunal Fiscal N ${ }^{\circ}$ 1507-5-2010, tal como señala Gamba Valega (2010):

(...) dejan en una desprotección absoluta al ciudadano contribuyente frente a actos de ejecución arbitrarios contenidos en órdenes de pago (incluso respecto de aquellas que no se sustenten en una deuda respecto de la que no se tenga certeza, por existir temas pendientes de discutir por parte del ciudadano contribuyente). Asimismo, de la lectura del precedente, se desprende claramente que, a juicio del TF, la única facultad que tiene el ejecutor coactivo respecto de la cobranza coactiva de órdenes de pago es la de verificar si se produjo o no su correcta notificación, olvidándose que la principal función del mencionado funcionario, es la de verificar la exigibilidad de la deuda tributaria a fin de iniciar el Procedimiento de Cobranza Coactiva, tal como expresamente reza el numeral 1 del artículo $116^{\circ}$ del Código Tributario. (p. 19)7

\footnotetext{
${ }^{6}$ Página 6 de la Resolución del Tribunal Fiscal No $15607-5-2010$.

${ }^{7}$ Según lo dispuesto por el numeral 1 del artículo $116^{\circ}$ del Código tributario, entre las facultades con las cuales cuenta el Ejecutor Coactivo, se encuentra la de verificar la exigibilidad de la deuda tributaria a fin de iniciar el Procedimiento de Cobranza Coactiva.
} 
Como señala el citado autor (2010), con anterioridad al referido pronunciamiento del Tribunal Fiscal, en casos en que la Administración pretendía ejecutar mediante órdenes de pago una supuesta deuda tributaria respecto de la cual no existía certeza “ (...) la última garantía con la que contaba el ciudadano-contribuyente para dejar sin efecto la cobranza coactiva - y por ende, evitar una ilegal afectación de su patrimonio - fue el control jurídico de parte del TF, mediante el procedimiento de queja." (p. 21)

Pues dicha garantía se ha esfumado con el nuevo criterio del Tribunal Fiscal, en tanto que dicho órgano colegiado ya no podrá efectuar, a través de la queja, control alguno respecto de la decisión tomada por el ejecutor coactivo de iniciar la cobranza coactiva de una orden de pago que contenga una deuda la cual no goza de certeza alguna, circunscribiéndose su función en dicho caso, a verificar únicamente la validez de la notificación de la orden de pago en cobranza.

El control sobre la validez de la orden de pago se podrá efectuar únicamente a través del procedimiento contencioso tributario, habiendo señalado así la Resolución $\mathrm{N}^{\circ} 15607-5-2010$ bajo análisis que:

Teniendo en consideración que es dentro del procedimiento contencioso tributario (procedimiento de reclamación) donde se emite pronunciamiento sobre la admisibilidad o no de un recurso de reclamación interpuesto, se concluye que solo dentro de dicho procedimiento compete analizar si se presenta el supuesto previsto en el numeral 3 del inciso a) del artículo $119^{\circ}$ del Código Tributario, esto es, analizar si existen circunstancias que evidencien la improcedencia de la cobranza de una orden de pago a efectos de admitir a trámite el recurso de reclamación.

Como veremos más adelante, la vía del procedimiento contencioso tributario no es para nada la adecuada para la defensa de los contribuyentes en los casos de cobranzas coactivas de deudas contenidas en órdenes de pago que no han sido emitidas de acuerdo a ley, y esto por diversos motivos, como la aplicación del solve et repete, o la demora en la emisión de pronunciamiento por parte de la Administración.

El problema central en el pronunciamiento emitido por el Tribunal Fiscal consideramos, está en la no diferenciación entre el control sobre la validez de la orden de pago por un lado, en el cual se cuestiona la exigencia de la deuda tributaria misma, ya sea por el fondo o por la forma, y por otro el control sobre la decisión del ejecutor coactivo de ejecutar una orden de pago, en el cual se cuestionará la certeza de la deuda 
contenida en dicho valor, esto es, si corresponde a un tributo autoliquidado o no, lo cual no tiene que ver con la legalidad o no de la orden de pago en cobranza. Así, coincidimos con Gamba Valega (2011) cuando concluye que:

(...) una cosa es evaluar si la orden de pago cumple las condiciones de certeza necesarias para su ejecución inmediata - lo que corresponde ser evaluado mediante el procedimiento de queja -, y otro, evaluar la legalidad de las órdenes de pago - lo que corresponde ser controlado mediante el procedimiento contencioso tributario -. Se trata de supuestos distintos, que, por lo demás, eran controlados con total normalidad por el TF con anterioridad al Acuerdo (...). (p. 34)

Con la vigencia del criterio antes citado, el Tribunal Fiscal ya no podrá analizar en vía de queja, las situaciones en las cuales la Administración, mediante la emisión de órdenes de pago, modifique o realice reparos respecto de las declaraciones juradas presentadas por los contribuyentes, casos en los cuales se emiten por lo general órdenes de pago bajo el amparo del numeral 3 del artículo $78^{\circ}$ del Código Tributario. Así, se podrá estar frente a la cobranza de valores que no tienen la naturaleza de órdenes de pago, al no corresponder a tributos autoliquidados por el deudor tributario, no obstante lo cual quedará al contribuyente deudor como única vía de salvación, la reclamación del valor que contiene la deuda en cobranza, con todas las implicancias que conllevará dicho procedimiento contencioso, lo que puede llevar a que vea afectado su patrimonio sin contar con medio de defensa efectivo.

\subsection{Reclamación contra la Orden de Pago - Solve Et Repete}

Sobre la base del derecho de defensa, las órdenes de pago pueden ser impugnadas por los deudores tributarios a través del recurso de reclamación, recurso el cual es resuelto por la propia entidad que emitió la orden de pago, siendo que de acuerdo a lo dispuesto por el artículo $136^{\circ}$ del Código Tributario es requisito para interponer reclamación contra una orden de pago, acreditar el pago previo de la totalidad de la deuda tributaria actualizada hasta la fecha en que se realice el pago, excepto en el caso establecido en el numeral 3 del artículo $119^{\circ}$ del referido código, esto es, cuando existan circunstancias que evidencien que la cobranza de la misma podría ser improcedente y siempre que la reclamación se hubiera interpuesto dentro del plazo de 20 días hábiles de notificada la orden de pago. 
Lo anteriormente señalado es lo que se conoce como el solve et repete, privilegio de la Administración Tributaria que muchos autores vienen considerando como un abuso que corresponden a criterios ya superados, y que contraviene principalmente el derecho a la tutela jurisdiccional efectiva. Al haberse consagrado en el siglo XX el acceso a la justicia en su sentido más amplio, incluyendo los procesos administrativos, también se han incluido otros derechos que se derivan del mismo, como lo es la gratuidad en el acceso a la justicia, lo cual ha hecho que se vaya rechazando dicha facultad de la Administración, la cual se sustenta principalmente en la presunción de legalidad de las órdenes de pago.

Tal como sostiene Villegas (2014, p.510 y 516), existe el error generalizado que la regla del solve et repete constituye un principio indiscutible en la doctrina, el cual es acogido por las diversas legislaciones del mundo sin discusión alguna, no obstante lo cual, y tal como hemos señalado previamente, dicha regla es muy discutida en la doctrina, y no generalmente aceptada en las legislaciones.

El referido autor (2014), señala al referirse a la regla bajo análisis que:

La regla solve et repete significa que cualquier contribuyente que en contienda tributaria le discuta al fisco la legalidad de un tributo, previamente debe pagarlo. Su origen se encuentra en el derecho romano, cuando en tiempos de la República, el edicto del pretor invirtió el orden normal del procedimiento, constituyendo a los contribuyentes en actores, para obtener la declaración de ilegitimidad de la pignoris causa otorgada a los publicanos (...). (p. 509)

La exigencia del pago previo como requisito para interponer recurso de reclamación contra un acto administrativo tributario, se da de manera específica en el caso de las órdenes de pago, al provenir las mismas por lo general de autoliquidaciones efectuadas por el propio contribuyente

Tal como hemos señalado, la orden de pago califica como un mandato de pago, que tiene como objeto la exigencia al deudor tributario, del pago de una deuda tributaria cierta y cuya cuantía es conocida con certeza, motivo por el cual debe ser plenamente exigible, siendo que sobre la base de dichas características es que se ha regulado la exigencia del pago previo para la reclamación.

Consideramos que no debe existir discrepancia alguna respecto a dicha exigencia en los casos de órdenes de pago relacionadas con deudas que el deudor 
reconoce pero no ha pagado, caso en el cual la Administración mediante la emisión de la respectiva orden de pago se limita a requerir el deudor que pague lo que él reconoce que debe; así, se busca evitar que la impugnación de deudas contenidas en actos de dicha naturaleza se use como medio para dilatar el cumplimiento de las obligaciones tributarias.

El Tribunal ha señalado en reiteradas resoluciones, tales como las $\mathrm{N}^{\circ} 1569-4-$ 2002, 1330-4-2003 y 2485-2-2003, entre otras, que la exigencia de pago previo no infringe el derecho de defensa de los contribuyentes, en tanto que dada la naturaleza de las Órdenes de Pago emitidas sobre la base del tributo autodeclarado y notificadas conforme a ley, la Administración lo que hace únicamente es exigir el pago de la deuda reconocida por el deudor tributario; criterio el cual compartimos, siempre y cuando se esté frente a Órdenes de Pago que no vulneren su propia naturaleza.

Respecto al requisito de pago previo también se ha pronunciado el Tribunal Constitucional, en la Sentencia No 3741-2004-AA/TC, en la que estableció como regla sustancial que:

Todo cobro que se haya establecido al interior de un procedimiento administrativo, como condición o requisito previo a la impugnación de un acto de la propia administración pública, es contrario a los derechos constitucionales al debido proceso, de petición y de acceso a la tutela jurisdiccional y, por tanto, las normas que lo autorizan son nulas y no pueden exigirse a partir de la publicación de la presente sentencia.

No obstante lo cual, la citada sentencia fue aclarada posteriormente por la emitida con ocasión del Expediente $N^{\circ}$ 04242-2006-PA/TC, en la que el Tribunal Constitucional señaló que descartaba de plano la posición de que ante una reclamación o apelación en el procedimiento contencioso-tributario, la Administración Tributaria o, de suyo, el Tribunal Fiscal estén impedidos de requerir el pago previo de la deuda en el caso de impugnación de órdenes de pago, conforme lo dispone el segundo párrafo del artículo $136^{\circ}$ del Código Tributario, indicando asimismo que:

(...) el supuesto previsto en la regla sustancial B de la STC 3741-2004-AA/TC es, a todas luces, distinto al de la impugnación de una orden de pago, donde la exigencia del pago previo no se origina debido a una tasa condicional para poder solicitar la revisión del caso, sino más bien debido a la existencia de deuda tributaria que el contribuyente tiene el deber de cancelar, conforme a los supuestos del artículo $78^{\circ}$ del Código 
Tributario" y añade que, "este requisito previo a la impugnación tampoco se origina necesariamente en un acto de la propia Administración Pública, sino, antes bien, en la constatación de una obligación sobre cuya cuantía se tiene certeza, la cual puede originarse, por ejemplo, cuando media lo declarado por el propio contribuyente (autoliquidación), supuesto que se constata con mayor claridad en los tres primeros incisos del artículo $78^{\circ}$ del Código Tributario. Es así que puede diferenciarse la naturaleza de una orden de pago de la resolución de determinación, en cuyo caso sí media un acto de fiscalización o verificación de deuda previo, siendo finalmente la Administración la que termina determinándola. De ahí que se exima al contribuyente del requisito del pago previo para su impugnación al no constituir aún deuda exigible.

Podemos señalar que las razones que justifican la aplicación del principio del solve et repete son las mismas que las de la autotutela, pero de manera específica la vinculada con la aplicación de medidas cautelares, como es el aseguramiento del éxito del proceso, evitando que el deudor disponga de su patrimonio. La presunción de legalidad respalda la aplicación de este principio, en vista que al encontrarse el origen de la Orden de Pago, por lo general, en una declaración del deudor tributario, este ha reconocido la obligación, la cual adquiere así mayor validez y certeza, más aún cuando tal como se ha precisado, el supuesto para la emisión de la Orden de Pago se da cuando el deudor ha incumplido con el pago dentro del periodo fijado a tales efectos y que tampoco lo hace de manera previa a la emisión del valor.

El solve et repete tiene como principal fundamento en su contra su supuesta inconstitucionalidad, al contravenir el derecho a la tutela judicial efectiva, no obstante lo cual, tal como se ha indicado previamente, el Tribunal Constitucional ya ha señalado que le referida exigencia no contraviene la Constitución en el caso de las Órdenes de Pago.

No obstante lo antes señalado, tal como hemos precisado la emisión de Órdenes de Pago según los supuestos establecidos en el artículo $78^{\circ}$ del Código Tributario no se encuentra exenta de controversias, principalmente en lo que respecta a las emitidas en base al numeral 3 del referido artículo, núcleo del presente trabajo de investigación, por lo que la exigencia del pago previo a efectos de admitir a trámite los recursos de reclamación puede presentarse en algunos casos como totalmente injusta y violatoria del derecho de defensa. 
El problema se torna aún más pernicioso para el contribuyente, teniendo en cuenta que según el criterio recogido por la previamente reseñada Resolución del Tribunal Fiscal $\mathrm{N}^{\circ}$ 15607-5-2010, será únicamente a través del recurso de reclamación que se podrá discutir la legalidad de una orden de pago.

Debe considerarse no obstante, tal como se ha referido previamente, que el Código Tributario establece de manera excepcional la no exigencia del pago previo en reclamaciones contra Órdenes de Pago, en los casos establecidos en el numeral 3 del artículo $119^{\circ}$ del referido cuerpo legal, esto es, en el caso se presenten circunstancias que evidencien que la cobranza de la misma podría ser improcedente y siempre que la reclamación se hubiera interpuesto dentro del plazo de 20 días hábiles de notificada la orden de pago.

Se aprecia así, que nuestro Código Tributario posibilita la admisión a trámite de la reclamación contra una Orden de Pago sin necesidad de efectuar el pago previo, si el referido recurso se presenta dentro del plazo de ley, y si se acreditan razones atendibles que amparen dicha reclamación, lo que implica que es el contribuyente interesado quien debe acreditar la improcedencia de la cobranza respecto de la Orden de Pago. La reclamación en la cual se solicita la dispensa del pago previo, deberá estar respaldada por elementos probatorios y argumentos que generen convicción en el órgano resolutor, para poder ser así ser admitido el referido recurso sin necesidad del pago previo.

La posibilidad otorgada por el artículo $119^{\circ}$ es basta, pudiendo otorgarse tanto por razones sustantivas como procedimentales, no existiendo un parámetro concreto al respecto. En la jurisprudencia del Tribunal Fiscal se encuentran diversos supuestos de razones atendibles para admitir a trámite reclamaciones sin necesidad de acreditar el pago previo según lo dispuesto por el artículo $119^{\circ}$ del Código Tributario. Así podemos citar los siguientes pronunciamientos:

- 1358-11-2011.- Del examen de la Orden de Pago impugnada, se advierte que si bien señala como base legal el artículo $78^{\circ}$ del Código Tributario, no indica el numeral 1 o 3 en base al cual se habría emitido, en tal sentido se ha omitido señalar los fundamentos que la amparan, no habiendo sido subsanada dicha omisión.

- 4106-11-2011.- De la revisión de la Orden de Pago impugnada se advierte que consigna como base legal los numerales 1 y 3 del artículo $78^{\circ}$ del Código Tributario, asimismo, la Administración no ha acreditado que el indicado valor se sustente en las declaraciones juradas que se mencionan en dicho valor. 
- 3431-9-2012.- Se revoca la apelada que declaró inadmisible la reclamación contra orden de pago girada por Impuesto a la Renta, toda vez que existen circunstancias que evidencian que la cobranza podría ser improcedente, pues la orden de pago impugnada no ha sido emitida en virtud a la declaración presentada por la recurrente, sino por el contrario, como resultado de desconocer la exoneración consignada por ésta en su declaración, no encontrándose ajustada a lo establecido en el numeral 1 del artículo $78^{\circ}$ del Código Tributario, norma en cuya base fue emitida.

- 09402-3-2010.- Las Órdenes de Pago impugnadas no detallan los motivos por los cuales se habría desconocido las liquidaciones efectuadas por la recurrente, siendo que de la documentación que obra en autos no se aprecia que la Administración haya subsanado tal omisión, existiendo así circunstancias que evidencian que la cobranza es manifiestamente improcedente, por lo que procede revocar la inadmisibilidad declarada por la Administración.

Coincidimos con Vivanco Ortiz (2012) cuando señala que:

Lamentablemente, el criterio de numerus apertus que ha optado el artículo $119^{\circ}$ del Código Tributario, puede desembocar en excesos y también abusos. Cuando las causales de otorgamiento de suspensión no están determinadas taxativamente, la arbitrariedad siempre será una amenaza, así como la excesiva discrecionalidad. La tares de los tribunales administrativos deberá cubrir esos riesgos a través de ejecutorias uniformes que marquen criterios por lo menos aproximados. (p. 797)

No obstante, consideramos que lo antes señalado es una dificultad con la que debemos enfrentarnos necesariamente, en tanto que de haberse optado por un criterio de numerus clausus respecto de las referidas causales, dicha opción conllevaría ya una elección discriminatoria, en tanto que sería imposible no dejar fuera de la lista situaciones que merecerían tal dispensa, sobre la base de supuestos ya existentes o que pueden surgir con el devenir del tiempo, en tanto que el derecho es una ciencia en constante evolución.

Debe indicarse asimismo, que la reclamación sin pago previo es una opción a cargo del deudor tributario respecto del cual se giró la Orden de Pago, quien por lo tanto también puede renunciar a la misma, impugnando el referido valor admitiendo el pago previo.

Podemos concluir así que a efectos de la admisión a trámite de una reclamación contra Órdenes de Pago sin necesidad de acreditar el pago previo de la deuda contenida 
en dichos valores, el recurrente se encontrará frente a la discrecionalidad de la Administración, quien deberá tener en cuenta los argumentos y pruebas que se expongan, en tanto no existe una lista taxativa de las causales a invocar; no obstante lo cual, la Administración deberá tener en cuenta los pronunciamientos que ha emitido el Tribunal Fiscal al respecto, pese a que la gran mayoría no tiene el carácter de jurisprudencia de observancia obligatoria.

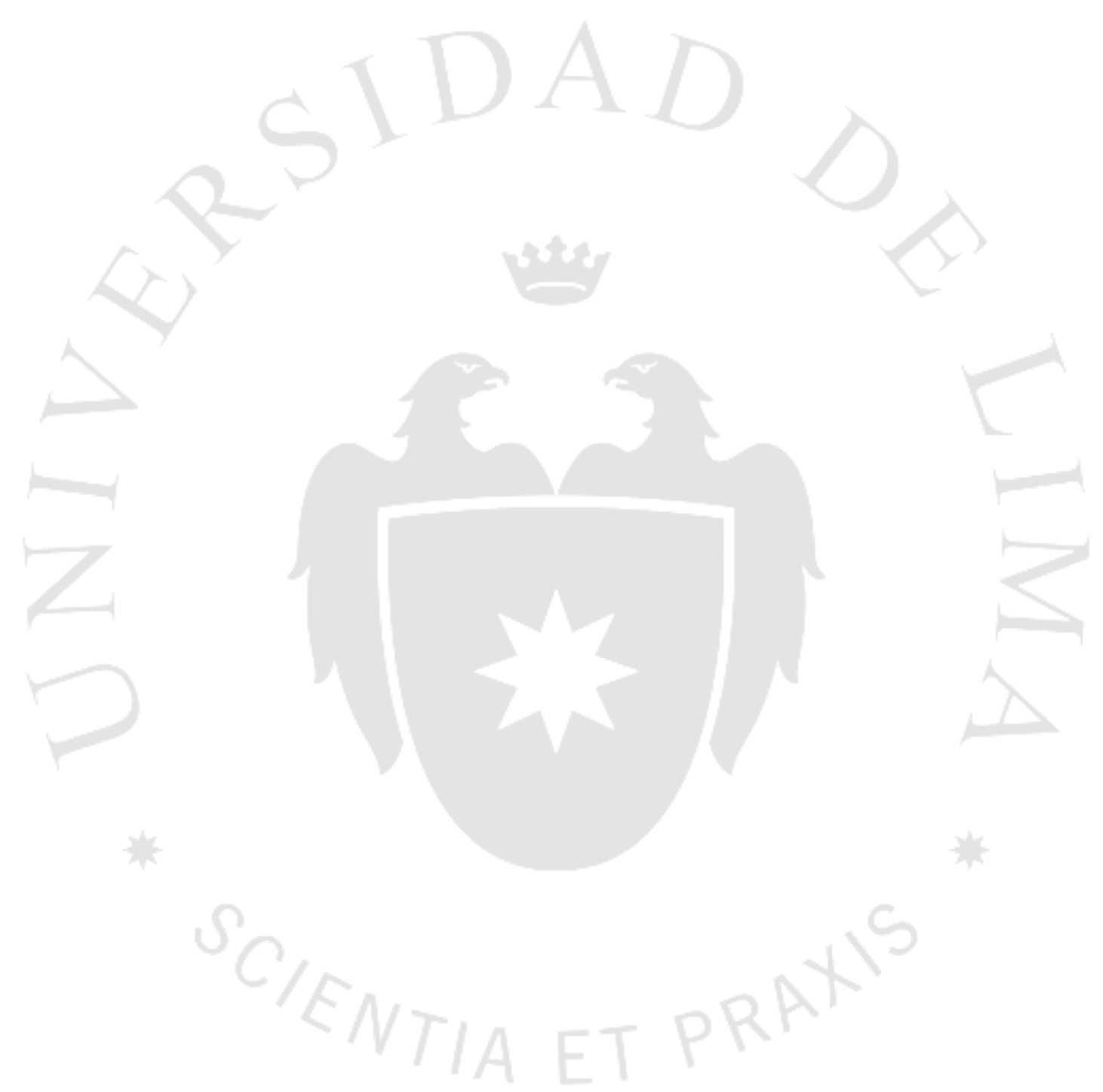




\section{CAPÍTULO III: NUMERAL 3 DEL ARTÍCULO 78 DEL CÓDIGO TRIBUTARIO}

Corresponde en este capítulo final, plantear el tema en sí de las órdenes de pago emitidas de conformidad con lo dispuesto en el numeral 3 del artículo $78^{\circ}$ del Código Tributario, para exponer nuestra posición en relación a la posición tomado por el legislador, así como nuestra posición al respecto y las opciones que se pueden presentar.

\subsection{Antecedentes}

En el Perú han existido a lo largo de su historia cuatro códigos tributarios, el primero que fue aprobado mediante Decreto Supremo $\mathrm{N}^{\circ} 263-\mathrm{H}$, posteriormente se tuvo el aprobado por Decreto Ley $\mathrm{N}^{\circ} 25859$, luego un tercero aprobado por Decreto Legislativo $\mathrm{N}^{\circ} 773$, y el cuarto aprobado por Decreto Legislativo $\mathrm{N}^{\circ} 816$.

En el primero de los códigos citados, el inciso 3 del artículo $87^{\circ}$ señalaba que procedía la emisión de un giro provisional, tratándose de situaciones en que medie la falta de pago del tributo que el obligado debió autoliquidar y pagar sin gestión previa del órgano acotador, entre otros, en el caso de errores materiales o de cálculo que hubiesen originado faltantes de pago.

Posteriormente, en el Código Tributario aprobado mediante Decreto Ley $\mathrm{N}^{\circ}$ 25859, se estableció en el numeral 3 del artículo $78^{\circ}$ que la Orden de Pago es el acto en virtud del cual la Administración exige al deudor tributario la cancelación de la deuda tributaria, sin necesidad de emitirse previamente la Resolución de Determinación, entre otros, en el caso de tributos derivados de errores materiales de redacción o de cálculo en las declaraciones, comunicaciones o documentos de pago.

El mismo texto es recogido en los subsiguientes códigos aprobados por Decreto Legislativo $\mathrm{N}^{\circ} 773$ y 816, agregándose no obstante que, a efectos de determinar el monto de la Orden de Pago, la Administración considerará la base imponible. 
A la fecha se encuentra vigente el Texto Único Ordenado del Código Tributario aprobado mediante Decreto Supremo No 133-2013-EF, que recoge las modificaciones al Decreto Legislativo $\mathrm{N}^{\circ}$ 816, entre otras, las del Decreto Legislativo $\mathrm{N}^{\circ}$ 953, que mediante su artículo $32^{\circ}$ sustituyó el numeral 3 del artículo $78^{\circ}$ del Código Tributario, cuyo texto es el vigente a la actualidad, y según el cual, procede la emisión de Órdenes de Pago:

Por tributos derivados de errores materiales de redacción o de cálculo en las declaraciones, comunicaciones o documentos de pago. Para determinar el monto de la Orden de Pago, la Administración Tributaria considerará la base imponible del período, los saldos a favor o créditos declarados en períodos anteriores y los pagos a cuenta realizados en estos últimos.

Para efectos de este numeral, también se considera el error originado por el deudor tributario al consignar una tasa inexistente.

El problema surge en el caso de las Órdenes de Pago emitidas en el supuesto bajo análisis, en tanto que lo que debe entenderse por "errores materiales de redacción o de cálculo en las declaraciones, comunicaciones o documentos de pago", no ha sido definido ni por la legislación ni por la jurisprudencia tributaria, lo cual no puede ser visto como algo de poca importancia, en tanto que la Administración ha venido aplicando dicha norma sobre la base de supuestos fácticos de muy distinta naturaleza, lo cual ha llevado a casos de extrema injusticia con los contribuyentes, que pueden encontrarse en estado de absoluta indefensión respecto de una deuda tributaria de la cual no tienen conocimiento alguno hasta el momento en que son notificados con la Orden de Pago correspondiente, la cual en muchos casos resulta ajena a la verdadera naturaleza de dichos valores, lo que en las actuales circunstancias, como ha sido previamente descrito, pueden causar un grave perjuicio.

Cabe indicar que al hacer referencia la norma a "tributos derivados de errores materiales de redacción o de cálculo en las declaraciones, comunicaciones o documentos", nos queda claro que, en principio, dicha norma se encontraba dirigida a los errores que se presentaban de manera constante en los periodos en los cuales las declaraciones eran presentadas, únicamente, vía formularios físicos, las cuales eran completadas manualmente por los deudores, esto es, las que podríamos llamar a "lápiz y papel". Esto es, su razón de ser estaba dada por la existencia de errores en la declaración que contenía la determinación de la obligación tributaria que era verificada 
por la Administración Tributaria, sin necesidad de efectuar remisión alguna a determinaciones de periodos anteriores que pudieran estar vinculados al revisado, lo cual resulta claro de la redacción originaria de la norma referida a dichos valores (numeral 3 del artículo $87^{\circ}$ del Código Tributario aprobado por decreto Supremo $\mathrm{N}^{\circ}$ 263-H); sin embargo, con el devenir de los años, se fue desnaturalizando el supuesto habilitante para la emisión de Órdenes de Pago de dicho tipo.

Nos preguntamos si en la actualidad, con la presentación de declaraciones juradas vía formularios virtuales, se pueden presentar las situaciones bajo las cuales se dictó originalmente la norma en cuestión, pudiendo encontrarnos ante una norma vigente pero que no rige, o más aún, preguntarnos si es pertinente que dicha norma siga vigente.

Es oportuno precisar la diferencia que existe entre una norma vigente y una norma que rige, para lo cual seguimos a Marcial Rubio (2009), quien señala al respecto:

La vigencia es un atributo teórico de la norma jurídica según el cual, de haber de haber sido debidamente producida de acuerdo a Derecho, debe ser aplicada y obedecida en la vida social. La norma, por otra parte, rige cuando la apreciación de carácter sociológico indica que tanto el supuesto como la consecuencia jurídica previstas, ocurren efectivamente en la realidad. La vigencia es un concepto, regir es un hecho. (p. 78)

Esto es, y tal como concluye el citado autor, pueden darse casos en los cuales normas que cumplen con los requisitos establecidos para su vigencia, no se apliquen en la realidad, en tanto que el supuesto planteado por la norma no se da en la realidad, lo que podría ocurrir en el caso bajo análisis, o porque dado el supuesto no se verifique la consecuencia establecida.

\subsection{Error material de redacción o de cálculo}

En primer lugar, y tal como hemos señalado, ni la legislación ni la jurisprudencia tributaria ha definido que es lo que debe entenderse por "errores materiales de redacción o de cálculo en las declaraciones, comunicaciones o documentos de pago", no obstante lo cual, el Tribunal Fiscal si ha establecido lo que debe entenderse por error material de redacción y error material de cálculo, pero para el caso de la aplicación de lo dispuesto en el numeral 2 del artículo $108^{\circ}$ del Código Tributario, relacionado con la posibilidad de la Administración de revocar, modificar, sustituir o complementar sus 
actos luego de su notificación, para lo cual la existencia de dicho tipo de errores es una habilitante.

Así, ha señalado el Tribunal Fiscal en Resoluciones tales como las $\mathrm{N}^{\circ}$ 00957-42010, 07535-2-2013 y 15611-1-2013, que resultará de aplicación lo dispuesto en el numeral 2 del artículo $108^{\circ}$ del Código Tributario, en los casos de error material de redacción o de cálculo, ocurriendo el error material de redacción cuando se consigna erróneamente un dato pero que de los actuado o del contenido de los documentos fluye la información correcta, en tanto que el error material de cálculo constituye una equivocación en alguna operación aritmética que conlleva a una cifra inexacta (error de suma, sustracción, multiplicación, división, etc.), lo cual se puede advertir del contenido de los documentos.

En cuanto a las referidas definiciones, debemos señalar en primer lugar que aquellas no corresponden a jurisprudencia de observancia obligatoria alguna; asimismo, las mismas se encuentran referidas a errores en que pueda incurrir la propia Administración al emitir sus actos y no a errores que pudieran cometer los contribuyentes al momento de efectuar la determinación de la obligación tributaria, lo que por su especial situación consideramos merece un análisis más profundo. Se tiene igualmente, que en dichas definiciones se hace referencia a que los errores pueden ser advertidos de lo actuado o del contenido de los documentos, lo que puede llevarnos en cierta medida a apreciar que no se encontrarían acordes con la naturaleza de las Órdenes de Pago según hemos indicado.

Así, consideramos necesario efectuar un análisis de lo que se deberá entender por error material, tanto de redacción y de cálculo, para llegar a una definición que pueda ser aplicada a lo dispuesto en el numeral 3 del artículo $78^{\circ}$ del Código Tributario, para lo cual podrá tenerse en cuenta, de ser el caso, lo dispuesto en las resoluciones del Tribunal Fiscal antes citadas.

Una primera aproximación ha dicho concepto, la tenemos en lo señalado por el Diccionario de la Real Academia de la Lengua, quien define al error como concepto equivocado o juicio falso; acción desacertada o equivocada; o cosa hecha erradamente.

Un concepto más amplio lo obtenemos del Diccionario de Derecho Usual de Cabanellas (1998), al señalar que el error es “equivocación, yerro, desacierto. Concepto 
equivocado o juicio inexacto o falso. Cosa imperfecta o contraria a lo normal, prescrito o convenido (...)". (T. II, p. 77)

Así, de manera general podemos definir al error como una equivocación, esto es, como una acción que no lleva a lo deseado, como la confusión de una cosa por otra debido a un descuido o al desconocimiento. Habiendo llegado a esta simple definición podemos preguntarnos ¿Es tan pacifica la conceptualización del error en relación a lo señalado por el numeral 3 del artículo $78^{\circ}$ del Código Tributario? Tengamos en cuenta en primer lugar, que la referida norma habla de "error material".

Al respecto, al tratadista español Boquera (1988), al referirse a los errores materiales indica que los mismos provienen “(...) de la equivocada manipulación de unos datos; propiamente, en estos supuestos, se trata de una errata, una mera equivocación; una errónea exteriorización de la voluntad de quien realiza el acto." (p. 177) Estamos entonces ante un error que no afecta la voluntad, que resulta manifiesto, así como ostensible, que es evidente por sí mismo, sin necesidad de efectuar mayores razonamientos y se manifiesta por su simple contemplación.

Estamos así ante un concepto muy amplio, el cual de por si abarca al error de redacción, como al error de cálculo, es decir, a los errores consistentes en simples equivocaciones que pueden cometerse por ejemplo al consignar un determinado número en lugar de otro, o por ejemplo, un error en la suma. En lo que respecta al error de cálculo (aritméticos), Meseguer (2001) señala que: "Los errores aritméticos consisten en simples equivocaciones cometidas al consignar un determinado número o el resultado de operaciones aritméticas sometidas a reglas claramente establecidas (una simple operación matemática permaneciendo fijos los sumandos o los factores).” (p. 15)

Debe indicarse que las posiciones más recientes de la doctrina hablan de un error material genérico, el cual comprende por un lado los denominados errores materiales estrictusensu, como lo serían los de redacción; y por otro lado los errores aritméticos o de cálculo.

Siguiendo a la jurista española Joana Socías (2002), consideramos como los requisitos esenciales que definen al error material los siguientes:

- Que se trate de simples equivocaciones elementales de nombres, fechas, operaciones aritméticas o transcripciones de documentos. 
- Que el error se aprecia teniendo en cuenta exclusivamente los datos del documento en el cual se advierte.

- Que el error sea patente y claro, sin necesidad de acudir a alguna interpretación de normas jurídicas aplicables.

- Que no se produzca una alteración fundamental en el sentido del acto, pues no existe error material cuando su apreciación implique un juicio valorativo o exija una operación de calificación jurídica. (p. 166)

Podemos concluir así, que existirá un error material de redacción o de cálculo en la determinación efectuada por el contribuyente, cuando de la declaración que contengan dicha determinación, y solo de esta, se verifique la existencia de datos consignados de manera errónea o equivocaciones en operaciones aritméticas, que influyan en dicha determinación.

Es importante tener en claro que cuando hacemos referencia a la ocurrencia de errores materiales de cálculo o redacción y la emisión de órdenes de pago, nos encontramos dentro del ámbito de la autodeterminación, esto es, la determinación de la obligación tributaria que es llevada a cabo por el sujeto pasivo de la obligación tributaria, en su calidad de contribuyente o responsable, o de las personas que ejerzan su representación, la cual se plasma por lo general en la declaración jurada, así, el error al que nos referimos proviene de dicho sujeto pasivo, siendo además que el error material debe encontrarse en la declaración jurada correspondiente al tributo y periodo por el cual se emitiría la correspondiente orden de pago.

Así, consideramos que el numeral 3 del artículo $78^{\circ}$ del Código Tributario debería ser modificado, a efectos que proceda la emisión de Órdenes de Pago, en los casos en que de la revisión de la declaración o documento que contenga la determinación de la obligación tributaria presentado por el contribuyente, y únicamente de ésta, se verifique la existencia de datos erróneos o errores de cálculo que influyan en la determinación efectuada. Consideramos que así, no se existirá desnaturalización alguna del concepto de Orden de Pago, como se ha venido presentando hasta la fecha 


\subsection{La declaración jurada}

Entre los principales deberes de los contribuyentes, incluso de terceros, es la elaboración y presentación de las declaraciones juradas tributarias, la cual puede ser definida de manera general, como el acto formal por el cual se comunica a la Administración Tributaria el acaecimiento de diversos hechos o actos que permitan determinar la obligación tributaria; no obstante lo cual, si bien su mención nos hace pensar casi de manera inmediata a la declaración determinativa, también se deben tener en cuenta las declaraciones informativas.

El Código Tributario define en su artículo $88^{\circ}$ a las declaraciones tributarias señalando que:

La declaración tributaria es la manifestación de hechos comunicados a la Administración Tributaria en la forma y lugar establecidos por Ley, Reglamento, Resolución de Superintendencia o norma de rango similar, la cual podrá constituir la base para la determinación de la obligación tributaria.

La Administración Tributaria, a solicitud del deudor tributario, podrá autorizar la presentación de la declaración tributaria por medios magnéticos, fax, transferencia electrónica, o por cualquier otro medio que señale, previo cumplimiento de las condiciones que se establezca mediante Resolución de Superintendencia o norma de rango similar. Adicionalmente, podrá establecer para determinados deudores la obligación de presentar la declaración en las formas antes mencionadas y en las condiciones que señalen para ello.

Los deudores tributarios deberán consignar en su declaración, en forma correcta y sustentada, los datos solicitados por la Administración Tributaria.

Se presume sin admitir prueba en contrario, que toda declaración tributaria es jurada.

Tal como se ha indicado, las declaraciones juradas pueden ser determinativas o informativas, en el caso de las primeras, como venimos señalando, se reconoce el nacimiento de la obligación tributaria y se liquida la correspondiente deuda o el crédito a favor; en tanto que en las segundas la finalidad es poner en conocimiento de la Administración Tributaria la realización de operaciones propias o de terceros. A efectos del presente trabajo de investigación, nos ocuparemos de las declaraciones juradas determinativas, las cuales serán objeto de análisis al encontrarse estrechamente vinculadas con la emisión de las Ordenes de Pago. 
Como ya se señaló previamente en cuanto a la determinación de la obligación tributaria, la misma se produce por un acto del propio contribuyente o por acción de la Administración Tributaria (dejamos de lado para nuestro caso la determinación mixta).

Nos interesa analizar el caso de la autodeterminación de la obligación tributaria y su plasmación. Como ya se ha señalado, dicha determinación es realizada por el propio contribuyente o responsable, por lo general a través de la declaración jurada, acto determinativo de la obligación tributaria que constituye un acto jurídico unilateral por el cual el deudor reconoce diversos hechos o actos que tienen relación con la generación de obligaciones tributarias, en la cual se señalaran datos relacionados con el hecho imponible realizado, se identifica al contribuyente o responsable, se calcula la base imponible del tributo así como se liquida el mismo aplicando la tasa correspondiente y los créditos que correspondan, de ser el caso, para finalmente determinar el monto a pagar.

En lo que respecta a la autoliquidación y la declaración, comentado el caso de la legislación española, Fernández Paves (1995) considera que:

(...) debemos separar con toda claridad tres ideas, tres actos distintos, realizados por un mismo sujeto e integrados en cierta forma bajo una misma realidad documental; me estoy refiriendo a la declaración tributaria en primer lugar, por lo que según reza el artículo 102.1. ${ }^{\circ}$ de la LGT, el particular manifiesta o reconoce espontáneamente ante la Administración tributaria, que se han dado o producido las circunstancias o elementos integrantes, en su caso, de un hecho imponible; a la autoliquidación tributaria, en segundo lugar, (...) que supone el cálculo por el particular del tributo derivado de aquel hecho imponible declarado; y a los posibles resultados de esta última, el pago o ingreso en su caso de la cantidad resultante de su práctica (...). (p. 77)

Cabe indicar que el citado autor señala posteriormente, de manera acertada a nuestro parecer, que realmente se integran en el documento únicamente la declaración y la autoliquidación.

La declaración jurada implica un juramento de veracidad, tal como indica el citado artículo $88^{\circ}$ del Código Tributario, esto es, estamos ante una declaración de hechos respecto de los cuales se presta juramento, lo cual implica que el declarante jura que lo declarado corresponde a la verdad. Así, parte de la doctrina considera a la declaración tributaria como una especie de confesión extrajudicial del deudor tributario, 
por lo que puede ser asumida como una prueba contra el declarante. Así podemos citar a Ramírez Cardona (1985) cuando señala que:

Por su contenido o materialidad y valor probatorio entre las partes (contribuyente y fisco), la declaración tributaria constituye una confesión del presupuesto objetivo de hecho de la obligación tributaria y su clasificación según las bases de depuración, principalmente en los impuestos de renta, industria y comercio y aduanas. $\mathrm{Y}$ al estar esas bases de depuración, integradas por rubros de los factores positivos (ingresos, ventas, activos) y negativos (costos, deducciones, pasivos), dicha confesión se tiene en cuenta en la totalidad de tales factores, tanto de los positivos que conducen a la determinación de un mayor valor del tributo como de los negativos o de menor valor, si son denunciados con los requisitos y pruebas especiales exigidos por la ley, según las bases aludidas, es por lo tanto, como toda confesión, la correspondiente a la declaración tributaria, indivisible (,,,); de manera que el fisco no puede tomar solo los factores positivos de depuración de la base gravable, sino que simultáneamente debe tomar también los negativos, como salvedades de aquellos, en cuanto disminuyen la base gravable y asimismo el valor del impuesto. (p. 275)

Otro sector de la doctrina no reconoce dicha característica a la declaración jurada, así tenemos a Jarach (1998), para quien “(...) la declaración tributaria tampoco es una confesión extrajudicial. Su función es solamente informativa y su valor depende de la existencia de medios de prueba, que conformen la veracidad de los datos suministrados en la declaración.” (p. 196)

La Ley del Procedimiento Administrativo General, en el numeral 42.1 de su artículo $42^{\circ}$, contiene una precisión importante respecto a las declaraciones juardas, al señalar que:

Todas las declaraciones juradas, los documentos sucedáneos presentados y la información incluida en los escritos y formularios que presenten los administrados para la realización de procedimientos administrativos, se presumen verificados por quien hace uso de ellos, así como de contenido veraz para fines administrativos, salvo prueba en contrario.

Al respecto, comenta Morón Urbina (2011):

La presunción de veracidad consiste en verdad en dos presunciones sucesivas que la Administración debe atender: i) presumir que han sido verificada la veracidad de los documentos sucedáneos que se presentan y la información que se consigna en las declaraciones juradas o en los escritos y demás formatos administrativos; y a 
continuación, ii) presumir que esos documentos y declaraciones son veraces para los fines del procedimiento en el cual se presentan. Como se puede apreciar, la primera presunción impide que una vez advertida la falsedad de la declaración o del documento presentado se pueda alegar que se desconocía su origen o la verdad de su contenido, es su deber verificar previamente su veracidad y hacerse responsable por ello ante la autoridad. Por la segunda presunción, la Administración debe suponer por adelantado y con carácter provisorio que los administrados proceden con verdad en sus actuaciones en los procedimientos en que intervienen, asumiendo la propia Administración la carga de la prueba sobre su presenta falsedad. (p. 259)

En el caso peruano, en la mayoría de los tributos, se asigna al deudor tributario la obligación de declarar los hechos imponibles y efectuar la liquidación del tributo. La misma situación se presenta en la Argentina, así el artículo $11^{\circ}$ del Texto Único Ordenado de la Ley 11.683, Ley de Procedimiento Tributario, señala que "la determinación y percepción de los gravámenes que se recauden de acuerdo con la presente ley, se efectuará sobre la base de declaraciones juradas que deberán presentar los responsables del pago de los tributos (...)" . Comentando lo señalado, Giuliani Fonrouge (2004) señala que:

Basta lo expuesto para comprender que la declaración jurada no constituye en este sistema un simple medio de informar a la administración la existencia de un hecho imponible, por lo cual es impropia la terminología del art. 11 de la recordada ley 11.683 cuando dice que la determinación se efectuará sobre la base de las declaraciones juradas, la cual solo hace conocer el hecho generador, únicamente, en la determinación mixta, cuando el contribuyente hace saber o denuncia circunstancias susceptibles de imposición y el fisco práctica la liquidación correspondiente, y también en la determinación de oficio sobre base cierta, pero resulta erróneo atribuirle alcance general. Solamente con el perjuicio administrativista de que la determinación debe ser, forzosa y necesariamente, un acto emanado de la administración, puede explicarse tal redacción; en nuestro concepto, empero, la autonomía jurídica del derecho financiero, permite concluir que el instituto de la determinación reviste caracteres peculiares que los distinguen de un procedimiento administrativo general. (437-438)

Consideramos correcto lo señalado por el precitado autor en relación a que la determinación efectuada por el contribuyente o responsable vía declaración jurada corresponde ya, valga la redundancia, a la determinación tributaria, no siendo necesario a tales efectos la intervención de la Administración Tributaria. 
La declaración tributaria en sí, implica el cumplimiento de una serie de obligaciones tributarias, tanto sustantivas como formales, en tanto que por un lado se reconoce la existencia de una deuda por la verificación del hecho imponible; de otro lado se reconoce la necesidad que dicha declaración se efectúe de manera correcta, exacta y sin omisiones, pues caso contrario implicará la aplicación de los correspondientes sanciones, siendo sustento así para que el Código Tributario considere como infracción sancionable con multa, el hecho de declarar cifras o datos falsos, tal como establece en su artículo $178^{\circ}$.

Debe tenerse en cuenta en lo que respecta a las declaraciones juradas, que el citado artículo $88^{\circ}$ del Código Tributario establece que la declaración referida a la determinación de la obligación tributaria podrá ser sustituida dentro del plazo de presentación de la misma; así, la declaración sustitutoria será la declaración que se realiza y se presenta dentro del plazo de vencimiento para la declaración, y cuyo efecto es sustituir o reemplazar a la presentada originalmente, no generando sanción alguna y surtiendo efectos desde su misma presentación.

Asimismo, el referido artículo $88^{\circ}$ establece que vencido el plazo para la presentación de la declaración jurada, está podrá ser rectificada dentro del plazo de prescripción, transcurrido el cual no podrá presentarse declaración rectificatoria alguna; señalando asimismo que la declaración rectificatoria surtirá efecto con su presentación siempre que determine igual o mayor obligación, en caso contrario, surtirá efectos si dentro de un plazo de cuarenta y cinco (45) días hábiles siguientes a su presentación la Administración Tributaria no emitiera pronunciamiento sobre la veracidad y exactitud de los datos contenidos en ella, sin perjuicio de la facultad de la Administración Tributaria de efectuar la verificación o fiscalización posterior.

Habiendo analizado el carácter de las declaraciones juradas determinativas, y siendo que su calidad de jurada le otorga naturaleza probatoria en contra del que la presenta y a favor de la Administración Tributaria, es que el órgano administrador se encuentra facultado a emitir Órdenes de Pago basándose en las declaraciones presentadas, cuando la deuda determinada no ha sido cancelada, en tanto la prueba la constituye la misma declaración, situación que se condice con la naturaleza de las Órdenes de Pago según la hemos determinado previamente. 
Así, no debería sorprender a ningún contribuyente la emisión de una Orden de Pago por un determinado tributo que ha sido objeto de determinación por el propio contribuyente a través de una declaración jurada y no ha sido cancelado en su oportunidad. La misma situación debería presentarse por ejemplo cuando un contribuyente anotó en su declaración jurada como base imponible de un tributo cualquiera, cuya tasa sea del 20\%, el monto ascendente a S/. 10 000,00, sin embargo en el rubro correspondiente al tributo por pagar señala S/. 1 000,00 cuando debió declarar S/. 2 000,00 teniendo en cuenta la tasa antes señalada, por lo que se le emite una Orden de Pago por la diferencia de S/. 1 000,00; en este caso el propio contribuyente podrá constatar el error de cálculo incurrido verificando su propia declaración jurada, teniendo en cuenta lo indicado en la Orden de Pago que le sea notificada.

La segunda situación antes descrita puede presentarse fácilmente en el caso de formularios pre impresos los cuales son llenados a mano, como podría ser el caso del Impuesto Predial en muchas municipalidades, o en años anteriores para todos los tributos administrados por la propia SUNAT. Sin embargo, nos reiteramos la pregunta, en los casos de declaraciones juradas presentadas por medios telemáticos ¿Puede presentarse dicha situación de error a la que hace referencia el numeral 3 del artículo $78^{\circ}$ del Código Tributario? Al respecto, debe tenerse en cuenta que la Superintendencia Nacional de Administración Tributaria - SUNAT tiene como práctica común el emitir Órdenes de Pago en base a la norma antes dispuesta, en el caso de tributos determinados por el propio contribuyente a través de declaraciones telemáticas.

Al respecto, mediante Resolución de Superintendencia $N^{\circ}$ 002-2000/SUNAT se dictaron disposiciones referidas a la utilización de programas de declaración telemática para la presentación de declaraciones, habiéndose definido al Programa de Declaración Telemática (PDT), como el medio informático desarrollado por la SUNAT para la presentación de declaraciones, y cuya utilización será establecida mediante Resolución de Superintendencia. Según lo señalado por la propia SUNAT en su página web (http: //www.sunat.gob.pe/institucional/publicaciones/revista_tributemos/tribut113/informe.ht m.):

Con este sistema, los contribuyentes pueden efectuar el pago de sus impuestos sin errores debido a que el programa efectúa las validaciones aritméticas y cálculos de tasa de manera automática, segura y rápida. Además, la declaración generada adquiere una 
codificación especial que sólo puede ser descifrada por el personal autorizado de la SUNAT.

Así, tenemos que es la propia SUNAT quien considera que en el caso de declaraciones juradas determinativas presentadas mediante PDT, no es posible que se presente la figura de los "errores materiales de redacción o de cálculo" en las declaraciones; sin embargo, y tal como hemos indicado, dicha Administración sigue emitiendo Ordenes de Pago bajo dicho concepto, en situaciones que son manifiestamente cuestionables, teniendo en cuenta la naturaleza de la orden de pago, según se ha definido.

Cabe señalar que si bien la SUNAT es la principal Administración Tributaria en el país en cuanto al número de contribuyentes y recaudación, tenemos también a las municipalidades, ya sean distritales o provinciales, con incidencia en un gran número de contribuyentes, y en cuyo caso, por lo general, no se da la posibilidad de presentar las declaraciones mediante programas telemáticos.

Podemos llegar a un primera conclusión, la cual es que no existe problema alguno en la emisión de Órdenes de Pago por "errores materiales de redacción o de cálculo" tal como dispone el numeral 3 del artículo $78^{\circ}$ del Código Tributario y teniendo en cuenta las definiciones a las que hemos arribado, en el caso de tributos auto determinados a través de formularios pre impresos los cuales son llenados a mano, situaciones las cuales se presentarán en el Perú no únicamente en el caso de tributos municipales u otros tributos no administrados por la SUNAT, como sería el caso de la Contribución al SENATI, sino en el caso incluso de tributos administrados por la misma SUNAT.

$\mathrm{Al}$ respecto, tenemos que mediante la Resolución de Superintendencia $\mathrm{N}^{\circ}$ 0902010/SUNAT se establecieron los lugares en los cuales los contribuyentes podrían seguir utilizando los formularios pre impresos 118 y 119, correspondientes al Régimen Especial y General IGV-RENTA, siendo que si bien dicha resolución de superintendencia habría sido derogada mediante la Primera Disposición Complementaria Derogatoria de la Resolución de Superintendencia $N^{\circ}$ 203-2012, en la página web de la SUNAT sigue apareciendo el listado de los lugares donde se podrán presentar los referidos formularios pre impresos, entre los que podemos citar el Distrito de Imaza, ubicado en la Provincia de Bagua del Departamento de Amazonas, el Distrito de Puquio, de la Provincia de Lucanas del departamento de Ayacucho, así como el Distrito de Iberia, de la Provincia de Tahuamanu del departamento de Madre de Dios, 
entre muchos otros, siendo igualmente que dicha información es la que se proporciona al hacer la consulta en línea y presencial ante la SUNAT.

Asimismo, el Tribunal Fiscal ha señalado en la Resolución $N^{\circ}$ 6234-9-2012, que incluso en caso que el contribuyente se encuentre obligado a presentar su declaración jurada vía PDT, la presentación de una declaración rectificatoria vía formulario pre impreso no implica que no se haya efectuado la rectificatoria, siendo en todo caso aplicable la infracción consistente en presentar las declaraciones, incluyendo las declaraciones rectificatorias, sin tener en cuenta la forma u otras condiciones que establezca la Administración Tributaria; así, según lo dispuesto por el Tribunal Fiscal, no podrá desconocerse la declaración efectuada mediante formulario pre impreso, aun cuando el contribuyente se encuentre en la obligación de utilizar el PDT.

Consideramos que en aplicación del Principio de Predictibilidad o Confianza Legítima, regulado en el numeral 1.15 del Artículo IV del Texto Único Ordenado de la Ley del Procedimiento Administrativo General, los contribuyentes domiciliados en los lugares señalados en la Resolución de Superintendencia Nº 090-2010/SUNAT, podrán seguir presentando sus declaraciones juradas determinativas mediante los referidos formularios pre impresos.

La pregunta que nos queda hasta acá es ¿es conveniente la emisión de una orden de pago bajo el supuesto establecido en el numeral 3 del artículo $78^{\circ}$ en el caso de declaraciones juradas efectuadas mediante PDT? En tanto que en dichos casos no pueden presentarse los errores materiales de cálculo o redacción, según la definición que hemos considerado.

Consideramos importante a efectos de responder nuestra interrogante, abordar el tema relacionado con el conocimiento que deben tener los contribuyentes respecto de las razones por las cuales se les emite una Orden Pago sobre la base de la norma en cuestión, esto es, que se les dé a conocer el error material que se le imputa, lo que se efectúa a través de la fundamentación de la Orden de Pago.

\subsection{Fundamentación en las Órdenes de Pago}

De acuerdo con lo señalado en el último párrafo del artículo $78^{\circ}$ del Código Tributario, las Órdenes de Pago que emita la Administración, en lo pertinente, tendrán los mismos requisitos formales que la Resolución de Determinación, a excepción de los motivos 
determinantes del reparo u observación. Así, teniendo en cuenta los requisitos de las Resoluciones de Determinación establecidos en el artículo $77^{\circ}$ del Código Tributario, tenemos que los requisitos formales con los que debe contar toda Orden de Pago son los siguientes: 1) El deudor tributario; 2) El tributo y el período al que corresponda; 3) La base imponible; 4) La tasa; 5) La cuantía del tributo y sus intereses; y, 6) Los fundamentos y disposiciones que la amparen.

El problema se centra en el requisito de la fundamentación de la Orden de Pago, por lo que debemos preguntarnos en primer lugar ¿Qué implica la fundamentación? Al respecto, según el Diccionario de la Real Academia de la Lengua, la fundamentación es la acción y efecto de fundamentar, esto es, establecer la razón de algo. Así, literalmente el fundamentar una Orden de Pago implica el señalar la razón por lo que dicho valor se emite, esto es, motivar la emisión de la misma ${ }^{8}$, y podemos llegar a esta conclusión teniendo en cuenta que como hemos definido previamente, toda Orden de Pago califica como un acto administrativo, respecto de los cuales la Ley del Procedimiento Administrativo General establece como uno de sus requisitos, la motivación, señalando al respecto en el numeral 6.1 de su artículo $6^{\circ}$ que "La motivación deberá ser expresa, mediante una relación concreta y directa de los hechos probados relevantes del caso específico, y la exposición de las razones jurídicas y normativas que con referencia directa a los anteriores justifican el acto adoptado."

Giuliani Fonrouge (2004) no hace diferencia entre fundamentación y motivación del acto, en tanto que al hablar de las resoluciones en las que consten las determinaciones de oficio, considera que:

Por cierto que la fundamentación o motivación del acto es imprescindible, para que sujeto pasivo sepa cuáles son las razones de hecho y de derecho que justifican la decisión y pueda hacer su defensa o, en su caso, deducir los recursos permitidos; y como es un requisito esencial de cualquier acto administrativo, aquélla también es necesaria en la determinación con base cierta, aunque fuere rectificativa de la formulada por el sujeto pasivo (declaración jurada), a pesar de que la ley no la mencione expresamente.(p. 451)

Dromi (1995) también hace referencia a dicho requisito, indicando que:

\footnotetext{
${ }^{8}$ Lo que es distinto al requisito establecido para el caso de las Resoluciones de Determinación referido al motivo determinante del reparo u observación, ya que por su propia naturaleza, no puede existir reparo u observación alguna en el caso de la emisión de una Orden de Pago.
} 
La motivación es la declaración de las circunstancias de hecho y de derecho que han inducido a la emisión del acto. Está contenida dentro de lo que usualmente se denominan considerandos. La constituyen, por tanto, los presupuestos o razones del acto. Es la fundamentación fáctica y jurídica de él, con que la Administración sostiene la legitimidad y oportunidad de su decisión.

La motivación del acto, es decir, las razones de hecho y de derecho que dan origen a su emisión, aclaran y facilitan la recta interpretación de su sentido y alcance, por constituir un elemento esencial del mismo (...). (p. 222)

La doctrina nacional también se ha pronunciado al respecto, en tal sentido, Morón Urbina (2011) señala que:

La exteriorización obligatoria de las razones que sirven de base o determinan una resolución de la Administración es denominada motivación. Para el régimen nacional, la motivación ha dejado de ser solo un elemento formal del acto administrativo, para inscribirse dentro del aspecto esencial de la sustancia del acto.

La exigencia de argumentar la orientación de los actos administrativos, es reconocida como el mecanismo necesario para permitir apreciar su grado de legitimidad y limitar la arbitrariedad de la actuación pública, dado que obliga al funcionario a razonar, reflexionar, a patentizar tanto la justificación de su acto como el objetivo perseguido con su emisión, con lo cual, brinda mayores posibilidades para evaluar si ejerce su competencia, circunscribiéndose solo a dictados de interés público, exponiendo un elemento valioso para una ulterior interpretación, calificación y control de su actuación en términos de objetividad y finalidad públicas. (p. 157)

Así, podemos concluir que la fundamentación en el caso de la emisión de una Orden de Pago, implica el señalar la razón por la cual se ha emitido dicho acto, así como señalar las normas en las cuales se sustenta su emisión.

En el caso preciso de las Órdenes de Pago emitidas sobre la base de lo dispuesto en el numeral 3 del artículo $78^{\circ}$ del Código Tributario, la fundamentación estará dada así por la indicación de los errores materiales de redacción o de cálculo que se hubiesen cometido. Así lo ha señalado el Tribunal Fiscal en diversa jurisprudencia, pudiendo citarse a manera de ejemplo la Resolución $N^{\circ}$ 16855-9-2013, en la cual se señala que las Órdenes de Pago impugnadas consignan como sustento el numeral 3 del artículo $78^{\circ}$ del Código Tributario, por “(...) error material de redacción o de cálculo en la determinación del tributo declarado en la declaración jurada de referencia"; no 
obstante lo cual, en los valores impugnados la Administración no había señalado los errores en que habría incurrido la recurrente y que originaron su emisión, esto es, dichos valores carecían de fundamento, los cuales recién fueron puestos en conocimiento de la recurrente en la resolución que resolvió su reclamación.

Al respecto, debe considerarse que una situación especial relacionada con el requisito de la fundamentación de las Órdenes de Pago, está dada por la nulidad o anulabilidad de dichos valores. A tales efectos, se tiene que de acuerdo a lo establecido por el numeral 2 del artículo $109^{\circ}$ del Código Tributario, son nulos los actos de la Administración Tributaria cuando son dictados prescindiendo totalmente del procedimiento legal establecido, o que sean contrarios a la ley o norma con rango inferior; en tanto que el inciso a) del referido artículo $109^{\circ}$ dispone que son anulables los actos de la Administración Tributaria dictados sin observar lo previsto en el artículo $77^{\circ}$, precisándose asimismo que los actos anulables serán válidos siempre que sean convalidados por la dependencia o el funcionario al que le correspondía emitir el acto.

Es pertinente hacer mención a los conceptos de nulidad y anulabilidad, según han sido tratados por la Ley del Procedimiento Administrativo General y la doctrina, en tanto que la normatividad tributaria no define de manera precisa dichas instituciones.

En lo que respecta a los efectos de la nulidad, la Ley del Procedimiento Administrativo General en su capítulo II trata sobre la nulidad de los actos administrativos, estableciendo en su artículo $12^{\circ}$ los efectos que conlleva la declaración de un acto como nulo:

12.1 La declaración de nulidad tendrá efecto declarativo y retroactivo a la fecha del acto, salvo derechos adquiridos de buena fe por terceros, en cuyo caso operará a futuro.

12.2 Respecto del acto declarado nulo, los administrados no están obligados a su cumplimiento y los servidores públicos deberán oponerse a la ejecución del acto, fundando y motivando su negativa.

12.3 En caso de que el acto viciado se hubiera consumado, o bien sea imposible retrotraer sus efectos, solo dará lugar a la responsabilidad de quien dictó el acto y en su caso, a la indemnización para el afectado.

Al respecto señala Morón Urbina (2011) que: 
La declaración administrativa o judicial de nulidad del acto administrativo hace que desaparezca la presunción que lo cobijaba y se descorra el velo de su engañosa legalidad. En tal sentido, la declaración operará hasta el momento mismo de su emisión, sin favorecer ni perjudicar a ningún administrado. (p. 172)

En lo que respecta a la nulidad, Stolfi (1959) ha señalado que:

Es nulo el negocio al que le falte un requisito esencial, o bien sea contrario al orden público o a las buenas costumbres, o bien infrinja una norma imperativa.

Para que haya nulidad no es necesario, por consiguiente, que sea declarada caso por caso, ya que viene impuesta como sanción conque la ley castiga en general la inobservancia de una norma coactiva. Por eso se dice generalmente que la nulidad puede ser expresa o tácita (...). La primera supone que el legislador la establezca expresamente (...). La segunda, en cambio, deriva lógicamente de la ley (...). (p. 80)

Marcial Rubio (1995) nos da una definición que consideramos acertada respecto a lo que se debe entender por nulidad, sobre la base de lo dispuesto por el ordenamiento jurídico nacional y la doctrina:

(...) como en todo caso de invalidez, la nulidad pertenece a la esfera de los intrínseco del acto, es decir, existe nulidad cuando uno de sus elementos esenciales presenta problemas desde la misma conclusión del acto, o cuando éste atenta contra una norma de orden público o contra las buenas costumbres. (pp. 19-20)

El mismo autor señala que la consecuencia esencial de la nulidad, es que convierte al acto respectivo en ineficaz y desde el inicio.

En cuanto a la anulabilidad, Albaladejo (1958) señala que:

El negocio anulable (también llamado impugnable), es plenamente eficaz, pero, por haberse celebrado con determinados defectos, está amenazado de destrucción, con la que se borrarían retroactivamente los efectos producidos. Se trata de un negocio provisionalmente válido (no hay invalidez actual) que, por tanto, modifica la situación jurídica preexistente (...). (p. 415)

Marcial Rubio (1995, pp. 32-33) señala una serie de elementos que caracterizan a la anulabilidad, entre los cuales se encuentran:

- El acto ha sido consumado con defectos que ameritan que sea inválido, cumplidos determinados requisitos. 
- El vicio que adolece el acto anulable puede ser convalidado de diversas formas a iniciativa de quien puede solicitar la anulación.

- El negocio anulable no es inválido per se sino eficaz y produce sus efectos de manera plena a partir de su consumación. Sin embargo, está amenazado de destrucción, es decir, tiene una invalidez pendiente.

Tenemos así que los actos administrativos pueden encontrarse viciados por estar incursos en causales de nulidad o de anulabilidad, en el caso de la nulidad, la misma conlleva vicios insubsanables por disposición expresa de la ley, lo que impide que el acto tenga validez jurídica; en tanto que la anulabilidad implica que un acto jurídico tiene vicios en su nacimiento o formación que pueden ser subsanados por la voluntad de las partes.

Al respecto, debe indicarse que de conformidad con lo señalado por los acápites 43 y 70 del Glosario de Fallos del Tribunal Fiscal aprobado mediante Acuerdo de Sala Plena N²013-31, antes de la aprobación del Acuerdo de Sala Plena 2016-04 del 19 de enero de 2016, la Orden de Pago devenía en nula cuando no había sido emitida conforme con el supuesto previsto en el artículo $78^{\circ}$ que sustenta su emisión; en tanto que en el caso que la reclamación contra la Orden de Pago hubiese sido admitida a trámite por la Administración y en la resolución apelada se convalidad el valor subsanando los requisitos previstos en el artículo $77^{\circ}$ del Código Tributario que hubiesen sido inobservados en su emisión, correspondía la remisión de los actuados a la Administración a efectos que se dé trámite de reclamación al recurso presentado, caso este último que corresponde al de un Orden de Pago anulable cuyo vicio ha sido subsanado.

Así, el Tribunal Fiscal emitió pronunciamiento respecto a la nulidad y anulabilidad en el caso de Órdenes de Pago emitidas por el numeral 3 del artículo $78^{\circ}$ del Código Tributario, en resoluciones en las cuales se aprecia los caracteres correspondientes a dichas figuras jurídicas.

En lo que respecta a la nulidad, tenemos las siguientes Resoluciones:

- 03786-10-2013.- La Orden de Pago fue girada por el Impuesto a la Renta, consignando como referencia la declaración jurada y como base legal el numeral 3 del artículo $78^{\circ}$ del Código Tributario; no advirtiéndose de autos sin embargo que dicho valor corresponda, en atención a la referida norma, a 
tributos derivados de errores materiales de redacción o de cálculo, por lo que la Orden de Pago impugnada deviene en nula, en aplicación de lo dispuesto por el numeral 2 del artículo $109^{\circ}$ del Código Tributario.

- 05399-1-2012.- La Orden de Pago fue emitida al amparo de lo dispuesto por el numeral 3 del artículo $78^{\circ}$ del Código Tributario, consignando que su emisión obedecía al "error material de redacción o de cálculo en la determinación del tributo declarado en la declaración jurada"; no obstante lo cual, se aprecia que la Administración no ha señalado los errores en que habría incurrido el recurrente y originan la emisión de dicho valor de conformidad con lo establecido en el artículo $77^{\circ}$ del Código Tributario, lo que tampoco se evidencia de la referida declaración, no habiendo la Administración convalidado la Orden de Pago en la resolución apelada, por lo que el referido valor deviene en nulo.

De otro lado, en cuanto a la anulabilidad tenemos lo señalado por las siguientes Resoluciones:

- 16855-9-2013.- En la cual se señala que al haberse puesto en conocimiento de la recurrente los fundamentos que amparan la emisión de las Ordenes de Pago impugnadas con la notificación de la resolución que resolvió el reclamo, los referidos valores han sido convalidados.

- 08321-1-2010.- En la cual se señala que al resolver la reclamación, la Administración ha convalidado la Orden de Pago impugnada.

No obstante lo cual, mediante Acuerdo de Sala Plena 2016-04 del 19 de enero de 2016 se ha adoptado el criterio según el cual procede declarar la nulidad del acto administrativo emitido como orden de pago, amparado en los numerales 1), 2) y 3) del artículo $78^{\circ}$ del Código Tributario, en aquellos supuestos en los que debió emitirse una resolución de determinación, dejándose sin efecto a la vez los antes citados acápites 43 y 70 del Glosario de Fallos, incorporándose el acápite correspondiente al criterio acordado

Tenemos que el Tribunal Fiscal ha dado un gran avance en lo que respecta a la naturaleza de las órdenes de pago con el precitado acuerdo de sala plena, en tanto que teniendo en cuenta la clara diferenciación entre la naturaleza de la orden de pago y de la resolución de determinación a la que ya hemos hecho referencia, ha señalado que: 
Por tanto, de girarse una orden de pago en aquéllos casos en los que correspondía girar una resolución de determinación, se prescindirá totalmente del procedimiento establecido y se habrá emitido un acto administrativo contrario a ley, por lo que se encontrará dentro del alcance del numeral 2) del artículo $109^{\circ}$ del citado código y en tal sentido, al existir un vicio grave, no corresponde subsanación alguna del acto administrativo sino su declaración de nulidad, considerando que, como se ha indicado anteriormente, el citado artículo 109 distingue y separa los actos nulos de los anulables previendo la posibilidad de convalidación sólo en el segundo caso.

Consideramos si, que el criterio acogido por el Tribunal Fiscal en este último Acuerdo de Sala Plena, surge de una doble interpretación que se presentaba en dicho ente administrativo respecto al tema señalado, la cual era consecuencia de una totalmente errada interpretación de las figuras de la orden de pago y de la resolución de determinación, puesto que el emitir una orden de pago en una situación en la cual lo que correspondía emitir era una resolución de determinación, en tanto se estaba cuestionando la determinación efectuada por el deudor tributario, implica una nulidad insalvable, esto es, de imposible subsanación, contrariamente a lo que se planteaba en algunos criterios recurrentes del Tribunal Fiscal, y que dieron como resultado a la existencia criterios divergentes en cuanto al tema.

Sin embargo, consideramos que seguirán existiendo algunas dificultades a pesar de lo señalado en el precitado acuerdo de sala plena, en tanto que se presentan muchos otros casos en los cuales podría darse la subsanación de una orden de pago girada omitiéndose alguno de los requisitos establecidos a tales efectos; así, podemos señalar el caso de una orden de pago emitida sobre la base de lo dispuesto en el numeral 3 del artículo $78^{\circ}$ del Código Tributario, pero sin señalarse de manera expresa cual habría sido el error material de redacción o de cálculo en que se ha incurrido, lo cual será recién indicado en la resolución que resuelve la reclamación interpuesta contra la orden de pago emitida.

En un caso como el antes citado, se deberá analizar si la fundamentación de la orden de pago que recién se pone en conocimiento del contribuyente a través de la resolución que resuelve la reclamación, corresponde efectivamente a la subsanación de la orden de pago emitida sobre la base del error material de redacción o de cálculo, esto es, se señala el error en que se habría incurrido, o si más bien, mediante la supuesta subsanación, lo que la Administración hace en realidad es evidenciar que lo que 
correspondía emitir era una resolución de determinación y no una orden de pago, caso en el cual éste último valor devendría en nulo y no en anulable, siguiendo el criterio establecido por el Tribunal Fiscal antes señalado.

Así, el Tribunal Fiscal ha emitido una serie de pronunciamientos con posterioridad al referido Acuerdo de Sala Plena, en los cuales ha dispuesto remitir los actuados a efectos que la Administración de trámite de reclamación al recurso de apelación presentado, en tanto que ha sido recién en la resolución apelada que la Administración ha puesto en conocimiento del contribuyente los fundamentos que sirven de sustento a la Orden de Pago emitida en virtud del numeral 3 del artículo $78^{\circ}$ del Código Tributario, entre las que podemos citar las siguientes:

- Resolución $\mathrm{N}^{\circ}$ 03636-10-2016.- En la cual se precisó en la apelada, que el valor se emitió como consecuencia del desconocimiento del saldo a favor del periodo anterior aplicado contra el Impuesto General a las Ventas resultante de mayo de 2015, precisando que la disconformidad se produjo en los meses de diciembre de 2005 y junio de 2006, en los cuales a la recurrente le correspondía un saldo a favor del periodo anterior menor, según sus declaraciones juradas.

- Resolución $\mathrm{N}^{\circ}$ 04156-10-2016.- En la cual se señaló en la apelada, que las órdenes de pago impugnadas se emitieron por el desconocimiento del coeficiente utilizado por la recurrente, debiendo aplicarse el coeficiente obtenido de la declaración jurada del Impuesto a la Renta del ejercicio anterior.

- Resolución $N^{\circ}$ 04245-5-2016.- En la cual la Administración señaló en la apelada, que el valor impugnado correspondía a la reliquidación de la deuda declarada por la recurrente, como consecuencia, entre otros, del desconocimiento parcial de los pagos a cuenta del ejercicio anterior conforme a la verificación de sus sistemas.

- Resolución $N^{\circ}$ 05867-2-2016.- En dicho caso, la Administración señaló en el anexo a las órdenes de pago impugnadas, que la reliquidación efectuada se sustentaba en la resolución de determinación emitida por el Impuesto a la Renta del ejercicio 2011, la cual desconocía parcialmente el saldo a favor originalmente declarado y aplicado a partir del pago a cuenta de abril de 
2012; no obstante lo cual, es recién en la apelada que se indicó que además de lo señalado en el citado anexo, las órdenes de pago impugnadas se sustentaban en la declaración jurada rectificatoria presentada por la recurrente por el Impuesto a la Renta del 2011, en la cual determinó un saldo a favor reconociendo las observaciones realizadas por la Administración en la fiscalización llevada a cabo, la que surtió efectos con su sola presentación al determinar mayor obligación. Concluye que las órdenes de pago impugnadas se sustentan en la declaración rectificatoria presentada y no en la resolución de determinación aludida, lo que se encuentra previsto en el numeral 3 del artículo $78^{\circ}$ del Código Tributario.

- Resolución $\mathrm{N}^{\circ}$ 06420-10-2016.- La Administración recién en la apelada explica las razones por las que procedió a emitir la orden de pago por el numeral 3 del artículo $78^{\circ}$ del Código Tributario, señalando que el saldo a favor se agotó en el mes de agosto de 2014 (la orden de pago es por febrero de 2015), precisando el motivo por el cual modifica el método a aplicar para la determinación de los pagos a cuenta.

\subsection{Hacía una modificación legislativa}

Según estipula el numeral 2 del artículo $98^{\circ}$ del Código Tributario, uno de los órganos que conforma el Tribunal Fiscal es la Sala Plena, compuesta por todos los vocales, y es el órgano encargado de establecer, mediante acuerdos de Sala Plena, los procedimientos que permitan el mejor desempeño de las funciones del Tribunal Fiscal así como la unificación de criterios de sus Salas, la misma que puede ser convocada de oficio por el Presidente del Tribunal Fiscal o a pedido de cualquiera de las Salas. Los Acuerdos de Sala Plena pueden adoptar dos tipos de acuerdo: i) jurisdiccionales (en tanto que adoptan criterios sobre cuestiones controvertidas en materia tributaria, interpretando de manera general el sentido y alcance de las normas tributarias y ii) Administrativos.

Se debe indicar que de acuerdo a lo establecido por el Acuerdo de Sala Plena No 2002-10 de fecha 17 de setiembre de 2002, los Acuerdos de Sala Plena tienen carácter vinculante para todos los vocales del Tribunal Fiscal.

Asimismo, en lo que respecta a las atribuciones del Tribunal Fiscal, el artículo $101^{\circ}$ del Código Tributario señala entre dichas atribuciones, el uniformar la 
jurisprudencia en las materias de su competencia, así como proponer al Ministerio de Economía y Finanzas las normas que juzgue necesarias para suplir las deficiencias en la legislación tributaria y aduanera.

Como se desprende de las normas antes reseñadas, en aplicación de sus atribuciones y mediante un Acuerdo de Sala Plena, el Tribunal Fiscal podría señalar que es lo que se debe entender por error material de cálculo o redacción en las declaraciones juradas, para que así se pueda determinar de una manera clara y definitiva, en qué casos corresponde emitir válidamente una orden de pago bajo dichos supuestos.

Consideramos la definición de error material de cálculo o redacción que hemos reseñado previamente como la más acorde a tales efectos, no obstante lo cual, existiría cierto hecho paradójico en caso se tome el camino antes indicado, ya que teniendo en cuenta la redacción del numeral 3 del artículo $78^{\circ}$ del Código Tributario en la actualidad, se daría el caso de órdenes de pago emitidas válidamente al amparo de dicha norma, las cuales no estarían acordes con la definición antes dada, por ejemplo en el caso de los saldos o créditos de ejercicios anteriores, o la aplicación del sistema para la determinación de los pagos a cuenta del Impuesto a la Renta, lo cual creemos demuestra la inconsistencia de la norma en cuestión, al permitir la emisión de órdenes de pago en caso en los cuales no existiría un error material de cálculo o redacción en la declaración jurada presentada por la recurrente.

Teniendo en cuenta la definición de error material de cálculo o redacción que hemos acogido, se presentarán casos en los cuales la Administración Tributaria, sin mediar dicho tipo de errores en las declaraciones presentadas por el contribuyente, en una revisión que podríamos llamar "de escritorio", y en virtud a declaraciones presentadas por el propio contribuyente por periodos distintos al examinado, o a actos de determinación que han obtenido la condición de firmes y consentidos, puede verificar que el tributo declarado no se ajusta a la realidad, sin necesidad de recurrir a un procedimiento de fiscalización que concluya con la emisión de una Resolución de Determinación.

Consideramos asimismo, que en dichos casos no correspondería la emisión de una orden de pago de conformidad con lo establecido en el numeral 3 del artículo78 ${ }^{\circ}$, en tanto que según la definición que hemos planteada, no existiría error material de redacción o cálculo alguno en la declaración presentada por la recurrente, sino que lo 
que se estaría presentando es que la referida determinación ya no se encontraría acorde con lo declarado por el propio contribuyente o lo determinado por la Administración respecto de periodos anteriores, esto si bien en la declaración jurada analizada no se verifica error material de cálculo o redacción alguno.

A manera de ejemplo, podemos señalar un primer caso en el cual el contribuyente presenta una declaración rectificatoria, la cual surte efectos de conformidad con lo establecido por el artículo $88^{\circ}$ del Código Tributario, modificando los datos consignados en su declaración jurada del Impuesto a la Renta correspondiente al ejercicio 2012 y en virtud de los cuales se procedió a determinar el sistema aplicable para la determinación de los pagos a cuenta de dicho impuesto por el ejercicio 2013. Así, al haber indicado en su declaración original del ejercicio 2012 la existencia de pérdida, correspondía se determinen los pagos a cuenta del ejercicio 2013 bajo el sistema del porcentaje (2\%); no obstante lo cual en su declaración rectificatoria determina la existencia de tributo por pagar, por lo que correspondería la aplicación del sistema del coeficiente para los pagos a cuenta del ejercicio 2013, respecto de los cuales la recurrente no presentó rectificatoria alguna. A la fecha, dicha situación conlleva a la emisión de forma valida, de una orden de pago sobre la base de lo establecido en el numeral 3 del artículo $78^{\circ}$ del Código Tributario

Un segundo caso ligado igualmente al Impuesto a la Renta y los pagos a cuenta de dicho impuesto, estará dado cuando la Administración inicia un procedimiento de fiscalización al contribuyente por el Impuesto a la Renta del ejercicio 2012, determinando la existencia de deuda tributaria por pagar y no de pérdida, por lo que el sistema de determinación de los pagos a cuenta de dicho impuesto aplicable al ejercicio 2013 debería variar de porcentaje a coeficiente, siendo que la determinación efectuada por la Administración ha quedado firme y consentida, en tanto no fue impugnada por el contribuyente o se emitió pronunciamiento en la última instancia administrativa (Tribunal Fiscal). El Tribunal Fiscal ha señalado que en dichos casos no correspondería la emisión de una orden de pago sino de una resolución de determinación

En ambos casos, consideramos no es necesario la iniciación de un procedimiento de fiscalización a efectos de verificar que la determinación de los pagos a cuenta de la recurrente correspondientes al ejercicio 2013 ha devenido en incorrecta, siendo en casos como los reseñados en que procederá la aplicación de la modificación normativa que 
planteamos, que se encuentra dirigida a la regulación de un tipo de valor que podríamos ver como intermedio entre la Orden de Pago y la Resolución de Determinación.

En tal sentido, consideramos indispensable se lleve a cabo una modificación legislativa a efectos de poder plasmar nuestra propuesta, para casos en los cuales no correspondería la emisión de una Orden de Pago teniendo en cuenta la naturaleza de dichos valores, pero tampoco sea necesario el inició un procedimiento de fiscalización a efectos de llegar a verificar el tributo que corresponde.

Así, consideramos que en casos como los antes señalados, la Administración deberá emitir un acto administrativo que como hemos señalado lo podemos ubicar en un punto intermedio entre una Orden de Pago y una Resolución de Determinación, el cual podría denominarse giro provisional a efectos de diferenciarlo de las Órdenes de Pago, el mismo que deberá ser notificado al contribuyente a efectos que éste pueda presentar la reclamación correspondiente, teniendo en cuenta que no se está ante una deuda en principio autodeterminada por el mismo, sino a verificaciones efectuadas por la Administración respecto de tributos autodeterminados por los contribuyentes, los cuales podrán verse modificados sobre la base de declaraciones presentadas por el propio contribuyente por periodos distintos al examinado y las cuales han surtido efectos de conformidad con lo dispuesto por el Código Tributario, o por actos de determinación efectuados por la Administración Tributaria y que adquieren la condición de firmes y consentidos.

Consideramos igualmente que en el caso planteado no correspondería que la Administración solicite la acreditación del pago previo a efectos de admitir a trámite la impugnación contra el referido giro provisional, en tanto no se está frente a un tributo autodeclarado por el deudor, o que sea resultado de un error material de cálculo o redacción en la declaración que contiene la determinación, esto es, no tiene la naturaleza de una orden de pago según se ha señalado, consideramos asimismo que en dicho procedimiento de reclamación, solo correspondería el cuestionamiento de los efectos de la declaración jurada presentada, o de la calidad de firme y consentida de la determinación efectuada por la Administración, respecto de periodos anteriores al analizado, motivo por el cual quizás se podría establecer que este procedimiento cuente con plazos cortos, tanto para la interposición de la impugnación, como para la resolución de la misma. 
La modificación planteada creemos permitirá a los contribuyentes mantener un mayor grado de certeza respecto a sus deudas tributarias, no viéndose sorprendidos así con Órdenes de Pago que contengan deudas respecto de las cuales no tienen un pleno conocimiento y que serán ejecutadas de manera casi inmediata. Asimismo, de considerar oportuno reclamar el giro provisional emitido en virtud a la modificación planteada, el deudor tendrá pleno conocimiento de la procedencia de la deuda, la que en este caso ya no podrá considerarse proveniente de "errores materiales de redacción o de cálculo", evitándose así los problemas que esto implica, y protegiéndose en un mayor grado el derecho de defensa, derecho fundamental de los deudores.

Podemos finalizar el presente trabajo, exponiendo las modificaciones legislativas que consideramos resultan pertinentes, según hemos concluido:

\section{Artículo $78^{\circ}$.- ORDEN DE PAGO}

La Orden de Pago es el acto en virtud del cual la Administración exige al deudor tributario la cancelación de la deuda tributaria, sin necesidad de emitirse previamente la Resolución de Determinación, en los casos siguientes:

3. Por tributos derivados de errores materiales de redacción o de cálculo en las declaraciones presentadas por el deudor tributario conteniendo la determinación de la obligación tributaria. Para determinar el monto de la Orden de Pago, la Administración Tributaria considerará únicamente los datos e información consignados por el deudor tributario en la declaración determinativa correspondiente al periodo cuya cancelación se solicita.

\section{Artículo $78^{\circ}$-A.- GIRO PROVISIONAL}

Corresponderá la emisión de un giro provisional, cuando la Administración verifique que la determinación efectuada por el deudor tributario en un periodo dado no es correcta, sobre la base de la revisión de declaraciones juradas presentadas por el deudor tributario, o de determinaciones efectuadas por la propia Administración que hayan adquirido la condición de firmes y/o consentidas, correspondientes a periodos anteriores respecto del cual se emite el referido giro provisional. 
A tales efectos, el deudor tributario contará con un plazo de cinco (5) días hábiles contados a partir del día siguiente de la notificación del giro provisional, a efectos de presentar la reclamación correspondiente, sin necesidad de acreditar pago previo alguno, pudiendo cuestionar en dicho caso únicamente los efectos de la declaración rectificatoria presentada o la calidad de firme y/o consentida de la determinación efectuada por la Administración, debiendo la Administración emitir pronunciamiento dentro de los veinte (20) días hábiles de presentada la reclamación.

Contra lo resuelto por la Administración, se podrá interponer recurso de apelación dentro de los cinco (5) días hábiles de notificada la resolución de la Administración, debiendo el Tribunal Fiscal emitir pronunciamiento dentro de los veinte (20) días hábiles de interpuesta la apelación. 


\section{CONCLUSIONES}

- Si bien existen discrepancias en la doctrina respecto a lo que se debe entender por obligación tributaria, el Código Tributario en su artículo $1^{\circ}$ al hablar de la obligación tributaria, se refiere de manera específica a la obligación sustancial, por la cual el sujeto activo tiene la pretensión, y el sujeto pasivo la obligación de dar una suma de dinero en cuanto se verifique la realización del hecho hipotético previsto en la ley a tales efectos. No obstante lo cual, existen a lo largo del referido código, una serie de obligaciones de carácter formal o accesorias.

Podemos definir a la obligación tributaria como el vínculo jurídico por el cual el deudor tributario se encuentra obligado a entregar al acreedor tributario sumas de dinero, en la mayoría de casos, o entregar bienes e incluso servicios en algunos casos, pero siempre estando ante una obligación de dar.

- En el Perú, adhiriéndose a la distinción terminológica seguida por Ataliba, y a diferencia de otras legislaciones como la española y la chilena por ejemplo, se diferencia entre hipótesis de incidencia, esto es el supuesto establecido en la norma tributaria, y hecho imponible, que es el hecho efectivamente acaecido en la realidad.

El concepto de hipótesis de incidencia lleva implícito el de sus cuatro aspectos, esto es, el aspecto subjetivo, que responde a la pregunta quien; el objetivo o material, que responde a la pregunta qué; el temporal que responde a la pregunta cuándo; y el espacial que responde a la pregunta dónde.

Consideramos que la base imponible no forma parte de los aspectos de la hipótesis de incidencia, siendo más bien la perspectiva mensurable del aspecto material.

- La determinación de la obligación tributaria implica la comprobación de la subsunción de un hecho acaecido en la realidad con todos los elementos de la hipótesis de incidencia, subsunción que debe ser total y no parcial.

Cabe hacer la distinción entre los términos determinación y liquidación, siendo que en la legislación nacional el término liquidación tiene un sentido restringido, vinculado al aspecto final del proceso de determinación de la obligación tributaria, específicamente con la cuantificación de la obligación. 
En nuestra opinión la determinación tiene naturaleza declarativa y no constitutiva, en tanto la obligación tributaria nace con la subsunción de un hecho en la realidad (hecho imponible), con el supuesto de la norma tributaria (hipótesis de incidencia), posición por la cual ha tomado partido nuestra legislación según lo dispuesto por el artículo $2^{\circ}$ del Código Tributario.

- La Orden de Pago tiene la naturaleza de un acto administrativo, propio de toda Administración Tributaria, por el cual exige el pago respecto de tributos autoliquidados por el deudor o responsable a través de una declaración jurada o, en los casos que no exista dicha liquidación, la misma será efectuada por la Administración, pero sobre la base de datos obtenidos del propio deudor y no cuestionados, no existiendo labor de determinación alguna por parte de la Administración.

El núcleo sobre el cual se debe partir para definir la naturaleza de la Orden de Pago, gira en torno a la ausencia de acto de determinación alguno por parte de la Administración Tributaria, de existir así el más mínimo acto de determinación vinculado a la emisión de una Orden de Pago, la misma se encontrará desnaturalizada.

- La cobranza coactiva de las deudas tributarias representa una facultad de la Administración Tributaria, que encuentra su sustento en la naturaleza pública del tributo, y a través de la cual exige coactivamente a los deudores tributarios la satisfacción de sus pretensiones, mediante la cancelación de las deudas pendientes.

La Orden de Pago tiene el carácter de deuda exigible coactivamente desde su notificación válidamente realizada, en tanto que en principio, proviene de una autodeterminación efectuada por el mismo deudor tributario y que no ha sido pagada; por lo que en dicho caso no es requisito para la exigibilidad que haya vencido el plazo para impugnarlas.

- La queja ha sido el medio de defensa con el cual cuentan los contribuyentes a efectos de defenderse de las cobranzas coactivas no seguidas de conformidad con la normatividad pertinente. No obstante lo cual, mediante el criterio de observancia obligatoria establecido por el Tribunal Fiscal en la Resolución $N^{\circ}$ 1507-5-2010, se ha determinado la imposibilidad de analizar en vía de queja , si la Orden de Pago en cobranza ha sido emitida con arreglo a lo dispuesto en el artículo $78^{\circ}$ del Código 
Tributario, así como la existencia de circunstancias que evidencien que la cobranza podría devenir en improcedente; habiéndose establecido que dichos temas deben ser vistos vía el recurso de reclamación, con los problemas que esto acarrea, vinculados especialmente con la aplicación del solve et repete.

- En cuanto al "error material de cálculo o redacción" al que hace referencia el numeral 3 del artículo $78^{\circ}$ del Código Tributario, el mismo se presentará cuando de la declaración que contengan la determinación de la obligación tributaria presentada por el deudor tributario, y solo de esta, se compruebe la existencia de datos consignados de manera errónea o equivocaciones en operaciones aritméticas, las cuales influyan en dicha determinación.

- La declaración tributaria es, por lo general, el acto a través del cual se plasma la autodeterminación efectuada por el contribuyente o responsable, acto determinativo de la obligación tributaria que constituye un acto jurídico unilateral por el cual se reconoce diversos hechos o actos que tiene relación directa con la generación de obligaciones tributarias. Siendo así, es que la Administración se encuentra facultada a emitir Órdenes de Pago basadas en dichas declaraciones, cuando la deuda correspondiente no ha sido cancelada.

- No existe problema alguno en la emisión de Órdenes de Pago por "errores materiales de cálculo o redacción", en el caso de tributos auto determinados a través de formularios pre impresos los cuales son llenados a mano; no siendo la misma situación en el caso de las declaraciones juradas determinativas presentadas mediante formularios PDT, tal como lo ha reconocido la propia SUNAT, al señalar que con dicho sistema los contribuyentes pueden efectuar el pago de sus impuesto sin cometer errores.

- Una primera modificación legislativa que consideramos pertinente se efectúe, se encuentra relacionada con el numeral 3 del artículo $78^{\circ}$ del Código Tributario, la cual debería considerar que proceda la emisión de Órdenes de Pago, en casos en los cuales de la revisión de la declaración o documento que contenga la determinación de la obligación tributaria presentado por el contribuyente, y únicamente de ésta, la Administración pueda verificar la existencia de datos erróneos o errores de cálculo que influyan en la determinación efectuada por el deudor tributario. 
- Nuestro planteamiento se centra en una modificación legislativa respecto de los casos en los cuales no correspondería la emisión de una Orden de Pago teniendo en cuenta la naturaleza de dichos valores, pero tampoco sea necesario el inició de un procedimiento de fiscalización a efectos de llegar a verificar el tributo correspondiente, específicamente en los casos en que la deuda auto determinada por el contribuyente pueda verse modificada sobre la base de declaraciones presentadas por el propio contribuyente respecto de periodos distintos al examinado o por actos de determinación que adquieren la condición de firmes y consentidos, todo lo cual podrá ser verificado en una simple revisión de escritorio por la Administración.

En casos como los antes señalados, la Administración deberá emitir un valor que podemos ubicarlo entre una Orden de Pago y una Resolución de Determinación, que podría ser denominado giro provisional, el cual deberá ser notificado al contribuyente a efectos que pueda presentar la reclamación correspondiente sin necesidad de acreditar el pago previo de la deuda contenida en el mismo, puesto que no estamos en estricto ante una deuda auto determinada por el contribuyente, no debiendo ser considerada como deuda exigible coactivamente con su sola notificación; asimismo, los plazos a efectos de la presentación de la reclamación y apelación, así para la resolución de los mismos, deben ser plazos cortos, cinco (5) día hábiles para la interposición del recurso impugnativo y veinte (20) para la resolución de los mismos. 


\section{REFERENCIAS}

Albaladejo, M. (1958). El Negocio Jurídico. Barcelona: Librería Bosch.

Ataliba, G. (1987). Hipótesis de Incidencia Tributaria. Lima: Instituto Peruano de Derecho Tributario.

Barros Carvalho. P. (2008). Obligación tributaria: definición, acepciones, estructura interna y límites conceptuales. En García Novoa, C. y Hoyos Jiménez, C. (Coord.). El tributo y su aplicación; Perspectiva para el siglo XXI (pp. 69 a 85). Madrid: Marcial Pons.

Boquera, O. (1998). Estudios sobre al acto administrativo. Madrid: Bosch.

Bravo Cucci, J. (2010). Fundamentos de Derecho Tributario. Lima: Juristas Editores.

Cabanelas, G. (1998). Diccionario de derecho Usual. Buenos Aires: Editorial Bibliográfica Ameba.

Calvo Ortega, R. (2000). Curso de Derecho Financiero. Madrid: Civitas. 2000.

Danos, J. (1995). El procedimiento de cobranza coactiva como manifestación de la potestad de la Administración Pública de ejecución forzosa de sus actos. Themis, (32), 43 - 50.

Decreto Supremo N 018-2008-JUS, Texto Único Ordenado de la Ley N²6979, Ley de Procedimiento de Ejecución Coactiva (6 de diciembre de 2008). Recuperado del sitio de internet del Sistema Peruano de Información Jurídica del Ministerio de Justicia: http://spij.minjus.gob.pe/libre/main.asp

Decreto Supremo N 133-2013-EF, Texto Único Ordenado del Código Tributario. (22 de junio de 2013). Recuperado del sitio de internet del Sistema Peruano de Información Jurídica del Ministerio de Justicia: http://spij.minjus.gob.pe/libre/main.asp

Decreto Supremo Nº06-2017-JUS, Texto Único Ordenado de la Ley del Procedimiento Administrativo General. (20 de marzo de 2017). Recuperado del 
sitio de internet del Sistema Peruano de Información Jurídica del Ministerio de Justicia: http://spij.minjus.gob.pe/libre/main.asp

Dromi, J. (1992). Derecho Administrativo. Buenos Aires: Editorial de Alfredo y Ricardo Depalma.

Fernández Paves, M. (1995). La autoliquidación tributaria. Madrid: Marcial Pons.

Gamba, C. (2010) Procedimiento de Cobranza Coactiva, Órdenes de Pago y desprotección de los Ciudadanos-Contribuyentes. Análisis Tributario, XXIII (275), $18-22$.

Gamba, C. (2011) ¿Deben controlarse las decisiones del ejecutor coactivo que ejecutan órdenes de pago en todos los casos, aun cuando no contengan deuda cierta? Análisis Tributario., XXIV (278), 32 - 35.

Giuliani Fonrouge, C. (2004). Derecho Financiero. Buenos Aires: La Ley.

Iannacone Silva, F. (2001) Código Tributario Comentado. Lima: Grijeley.

Jarach, D. (1999). Finanzas Públicas y Derecho Tributario. Buenos Aires: AbeledoPerrot.

Jarach, D. (1982). El Hecho Imponible. Buenos Aires: Abeledo Perrot.

Meseguer Yebra, J. (2001). La rectificación de los errores materiales, de hecho y aritméticos en los actos administrativos. Madrid: Bosch.

Morón Urbina, J. (2011). Comentarios a la Ley del Procedimiento Administrativo General. Lima: Gaceta Jurídica.

Nava Tolentino, J. (2007). Análisis de la exigibilidad y cobranza coactiva de la orden de pago: a propósito de la sentencia del Tribunal Constitucional. Análisis Tributario, $X X$ (239), $24-26$.

Palao, C. (1980). Ordenanza Tributaria Alemana). Madrid: Instituto de Estudios Fiscales.

Rubio, M. (1995). La invalidez del acto jurídico. Lima: Fondo editorial de la Pontificia Universidad Católica del Perú.

Rubio, M. (2009). El Sistema Jurídico. Introducción al Derecho. Lima: Fondo editorial de la Pontificia Universidad Católica del Perú. 
Saénz Rabanal, M. (1996). Facultades de la administración tributaria en materia de determinación de tributos. Revista del Instituto Peruano de Derecho Tributario. (30), $103-119$.

Sainz de Bujanda, F. (1993). Lecciones de Derecho Financiero. Madrid: Universidad Complutense.

Socias, J. (2002). Error material, error de hecho y error de derecho. Concepto y mecanismos de corrección. Revista de Administración Pública, (157), 157 - 211

Sotelo, E. (1996). Algunas reflexiones sobre el procedimiento de cobranza coactiva de tributos. Themis, (34), 231 - 241.

Spisso, R. (1996). Tutela judicial efectiva en materia tributaria. Protección del contribuyente ante el estado de sitio fiscal. Buenos Aires: De Palma.

Stolfi, G. (1959). Teoría del Negocio Jurídico. Madrid: Editorial

Talledo Mazú, C. (1999). La determinación como acto jurídico. Cuadernos Tributarios. Asosciación Fiscal Internacional (IFA), (23). 85 - 97.

Talledo Mazu (2013). Manual del Código Tributario. Lima: Editorial Economía y Finanzas.

Vera Regalado, P. (2002). Cobranza coactiva de la deuda tributaria en los últimos 10 años: caso SUNAT (tesis de maestría). Universidad de Lima, Lima Perú.

Villegas, Héctor B. (2002). Curso de Finanzas, Derecho Financiero y Tributario. Buenos Aires: Astrea.

Vivanco Ortiz, A. (2012). La suspensión de la ejecución de la deuda tributaria sin pago previo de la misma, como consecuencia de la presentación del recurso de reclamación. En D. Yacolca (Director). Tratado de Derecho Tributario procesal (pp. 775 a 798). Lima: Pacífico Editores. 